\title{
Words that Wound: A Tort Action for Racial Insults, Epithets, and Name-Calling
}

Richard Delgado

University of Alabama - School of Law, rdelgado@law.ua.edu

\section{Recommended Citation}

Richard Delgado, Words that Wound: A Tort Action for Racial Insults, Epithets, and Name-Calling, (2012). Available at: https://scholarship.law.ua.edu/fac_working_papers/213 


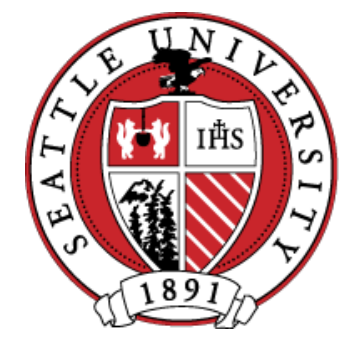

\section{SEATTLE U N I V E RS I T Y SCHOOL OF LAW}

\section{WORDS THAT WOUND: A TORT ACTION FOR RACIAL INSULTS, EPITHETS, AND NAME-CALLING}

Richard Delgado

Professor of Law

Published in the Harvard Civil Rights-Civil Liberties Law Review, Vol. 17 (1982)

This paper can be downloaded without charge from the Social Science Research Network Electronic Paper Collection

Standing for excellence. Reaching for justice. 


\title{
WORDS THAT WOUND: A TORT ACTION \\ FOR RACIAL INSULTS, EPITHETS, \\ AND NAME-CALLING $\uparrow$
}

\author{
Richard Delgado*
}

\section{Introduction}

Five years ago in Contreras $v$. Crown Zellerbach, Inc. ${ }^{1}$ the Washington Supreme Court held that a Mexican-American's allegations that fellow employees had subjected him to a campaign of racial abuse stated a claim against his employer for the tort of outrage. ${ }^{2}$ The plaintiff alleged that he had suffered "humiliation and embarrassment by reason of racial jokes, slurs and comments"3 and that the defendant's agents and employees had wrongfully accused him of stealing the employer's property, thereby preventing him from gaining employment and holding him up to public ridicule. Focusing upon the alleged racial abuse, the court declared that "racial epithets which were once part of common usage may not now be looked upon as 'mere insulting language." "4

Eleven months later, the United States Court of Appeals for the Seventh Circuit in Collin v. Smith ${ }^{5}$ affirmed a federal

$\dagger$ The author is deeply indebted to the following individuals for their help and encouragement during the preparation of this article: Lisa Frye; Peter McAllen; Karen Perret; Gary Schwartz, Professor of Law, UCLA; and Steve Shiffrin, Professor of Law, UCLA.

*J.D. University of California, Berkeley, 1974. Professor of Law, UCLA Law School.

188 Wash. 2d 735, 565 P.2d 1173 (1977)(en banc).

2 The tort is also known as "intentional infliction of emotional distress." See id. at 737 n.1, 565 P.2d at 1174 n.1 (quoting Restatement (Second) of Torts $\S 46(1)$ (1965) : "One who by extreme and outrageous conduct intentionally or recklessly causes severe emotional distress to another is subject to liability for such emotional distress....").

${ }^{3} 88$ Wash. $2 \mathrm{~d}$ at 736,565 P.2d at 1174 .

${ }^{4} I d$. at 741,565 P.2d at 1177.

s 578 F.2d 1197 (7th Cir.), cert. denied, 439 U.S. 916 (1978). 
district court's decision declaring unconstitutional certain ordinances of the Village of Skokie, Illinois, which had been drafted to block a demonstration by members of the National Socialist Party of America. ${ }^{6}$ The village argued that the demonstration, together with the intended display of Nazi uniforms and swastikas, would inflict psychological trauma on its many Jewish citizens, some of whom had lived through the Holocaust. The court of appeals acknowledged that "many people would find [the] demonstration extremely mentally and emotionally disturbing."7 Mentioning Contreras, the court also noted that Illinois recognizes the "new tort" of intentional infliction of severe emotional distress, which might well include the uttering of racial slurs. ${ }^{8}$ Nevertheless, the threat of criminal penalities imposed by the ordinance was held impermissibly to abridge the plaintiffs' first amendment rights. ${ }^{9}$

The concatenation of these two cases and the unsettled condition in which Collin leaves tort actions for racial speech suggest that reappraisal of these tort actions is in order. This Article will argue that an independent tort action for racial insults is both permissible and necessary. The Article will first examine the harms caused by racism and racial insults to the victims, to the perpetrators, and to society as a whole. It will then examine the various doctrines under which plaintiffs have brought lawsuits for racial insult, concluding that these doctrines fail to provide adequate protection against such language. The Article will next consider objections to an independent tort that are based on the difficulty of apportioning damages and on first amendment con-

${ }^{6} I d$. at 1210. One of the ordinances prohibited the "dissemination of any materials... which promotes and incites [sic] hatred against persons by reason of their race" and made violations punishable by fine or imprisonment.

${ }^{7}$ Id. at 1200 .

"Id. at $1206 \&$ n.17 (court "intimate[s] no views" on whether specific individuals could recover damages caused by such a demonstration and whether first amendment would bar such an action). The lower court in Collin also refused to reach the question of the constitutional validity of a tort for racial insults. See Collin v. Smith, 447 F. Supp. 676, 695 n.12 (N.D. Ill. 1978)("The federal courts should be hesitant to sweepingly invalidate state laws where narrower rulings will adequately protect constitutional rights.").

9578 F.2d at 1202-07. 
cerns. The Article will conclude with a brief sketch of the contours of the proposed cause of action.

\section{Psychological, Sociological, and Political Effects of Racial Insults}

American society remains deeply afflicted by racism. Long before slavery became the mainstay of the plantation society of the antebellum South, Anglo-Saxon attitudes of racial superiority left their stamp on the developing culture of colonial America. ${ }^{10}$ Today, over a century after the abolition of slavery, many citizens suffer from discriminatory attitudes and practices, infecting our economic system, our cultural and political institutions, and the daily interactions of individuals. ${ }^{11}$ The idea that color is a badge of inferiority and a justification for the denial of opportunity and equal treatment is deeply ingrained.

The racial insult remains one of the most pervasive channels through which discriminatory attitudes are imparted. ${ }^{12}$ Such language injures the dignity and self-regard of the person to

${ }^{10}$ See generally A. Higginbotham, In the Matter of Color (1978).

"See G. Allport, The Nature of Prejudice 77-78 (1954)(studies led researchers to estimate that four-fifths of American population harbored enough antagonism toward minority groups to influence their daily conduct); $i d$. at 197-98 ( $84 \%$ agreement among college students for stereotype of blacks as superstitious). See generally Report of the National Advisory Commission on Civil Disorders (Kerner Commission) 203-82 (N.Y. Times ed. 1968).

${ }^{12}$ Despite recent civil rights activism, verbal racism has not disappeared. See, e.g., Racism Flares on Campus, Time, Dec. 8, 1980, at 28 ("stinking black monkeys" and other messages sent to black students at Williams College; black student leader at Harvard University found her office calendar defaced with racist slogans; crosses burned at Purdue University; letter addressed to black student dormitory at Wesleyan University spoke of "wip[ing] all g.d. niggers off the face of the earth"). A black dean at Harvard University attributed the recent upsurge in racist slurs and acts to a change in national mood, which has made such acts "once again. . respectable." Id. See also McQueen, The Anguish and Humiliation of Interracial Couples, Sacramento Bee, Feb. 5, 1981, § C, at 4, col. 1; Trescott, Is Social Racism Now Becoming “Acceptable?,” L.A. Times, June 12, $1981, \S \mathrm{V}$, at 2, col. 1 ("the veiled insult, contempt masquerading as a joke, [and] the direct slur," underground in 1960's and early 1970's, now being "recycled . . . as a protest against minority gains"). 
whom it is addressed, communicating the message that distinctions of race are distinctions of merit, dignity, status, and personhood.13 Not only does the listener learn and internalize the messages contained in racial insults, ${ }^{14}$ these messages color our society's institutions and are transmitted to succeeding generations. ${ }^{15}$

\section{A. The Harms of Racism}

The psychological harms caused by racial stigmatization are often much more severe than those created by other stereotyping actions. Unlike many characteristics upon which stigmatization may be based, membership in a racial minority can be considered neither self-induced, like alcoholism or prostitution, nor alterable. Race-based stigmatization is, therefore, "one of the most fruitful causes of human misery. Poverty can be eliminated-but skin color cannot."16 The plight of members of racial minorities may be compared with that of persons with physical disfigurements; the point has been made that

[a] rebuff due to one's color puts [the victim] in very much the situation of the very ugly person or one suffering from a loathsome disease. The suffering . . . may be aggravated by a consciousness of incurability and even blameworthiness, a self-reproaching which tends to leave the individual still more aware of his loneliness and unwantedness. ${ }^{17}$

The psychological impact of this type of verbal abuse has been described in various ways. Kenneth Clark has observed, "Human beings . . . whose daily experience tells them that almost nowhere in society are they respected and granted the ordinary dignity and courtesy accorded to others will, as a matter of

\footnotetext{
${ }^{13}$ See infra text accompanying notes 57-70.

14 See infra text accompanying notes 18-22 \& 72-76.

is See infra text accompanying notes 44-53.

${ }^{16}$ P. Mason, Race Relations 2 (1970).

" O. Cox, Caste, Class and Race 383 (1948).
} 
course, begin to doubt their own worth."18 Minorities may come to believe the frequent accusations that they are lazy, ignorant, dirty, and superstitious." "The accumulation of negative images . . . present $[\mathrm{s}]$ them with one massive and destructive choice: either to hate one's self, as culture so systematically demand[s], or to have no self at all, to be nothing."20

The psychological responses to such stigmatization consist of feelings of humiliation, isolation, and self-hatred. Consequently, it is neither unusual nor abnormal for stigmatized individuals to feel ambivalent about their self-worth and identity. ${ }^{21}$ This ambivalence arises from the stigmatized individual's awareness that others perceive him or her as falling short of societal standards, standards which the individual has adopted. Stigmatized individuals thus often are hypersensitive and anticipate pain at the prospect of contact with "normals."22

It is no surprise, then, that racial stigmatization injures its victims' relationships with others. Racial tags deny minority individuals the possibility of neutral behavior in cross-racial contacts, ${ }^{23}$ thereby impairing the victims' capacity to form close interracial relationships. Moreover, the psychological responses of self-hatred and self-doubt unquestionably affect even the victims' relationships with members of their own group. ${ }^{24}$

The psychological effects of racism may also result in mental illness and psychosomatic disease. ${ }^{25}$ The affected person may

${ }^{18} \mathrm{~K}$. Clark, Dark Ghetto 63-64 (1965).

${ }^{19}$ See G. Allport, supra note 11, at 152.

${ }^{20} \mathrm{~J}$. Kovel, White Racism: A Psychohistory 195 (1970).

${ }^{21}$ See E. Goffman, Stigma 7 (1963). See also J. Griffin, Black Like Me (1960)(white journalist dyed skin, assumed black identity, traveled through South, was treated as a black; began to assume physical demeanor and psychological set of black itinerant).

${ }^{22}$ See E. Goffman, supra note 21, at 17, 131.

${ }^{23}$ See S. Hayakawa, Symbol, Status, and Personality 76-78 (1966).

${ }^{24} \mathrm{See}$, e.g., G. Allport, supra note 11, at 9, 148-49; M. Goodman, Race Awareness in Young Children 46-47, 55-58, 60 (rev. ed. 1964). See also Cota Robles de Suarez, Skin Color as a Factor of Racial Identification and Preference of Young Chicano Children, Chi. J. Soc. Sci. \& Arts, Spring 1971, at 107; Stevenson \& Stewart, A Developmental Study of Racial Awareness in Young Children, 29 Child Dev. 399 (1958).

${ }^{25}$ See, e.g., Harburg, Erfurt, Havenstein, Chape, Schull \& Schork, Socio- 
react by seeking escape through alcohol, drugs, or other kinds of anti-social behavior. The rates of narcotic use and admission to public psychiatric hospitals are much higher in minority communities than in society as a whole. ${ }^{26}$

The achievement of high socioeconomic status does not diminish the psychological harms caused by prejudice. The effort to achieve success in business and managerial careers exacts a psychological toll even among exceptionally ambitious and upwardly mobile members of minority groups. Furthermore, those who succeed "do not enjoy the full benefits of their professional status within their organizations, because of inconsistent treatment by others resulting in continual psychological stress, strain, and frustration."27 As a result, the incidence of severe psychological impairment caused by the environmental stress of prejudice and discrimination is not lower among minority group members of high socioeconomic status. ${ }^{28}$

One of the most troubling effects of racial stigmatization is that it may affect parenting practices among minority group members, thereby perpetuating a tradition of failure. A recent study ${ }^{29}$ of minority mothers found that many denied the real significance of color in their lives, yet were morbidly sensitive to matters of race. Some, as a defense against aggression, identified excessively with whites, accepting whiteness as superior. Most had negative expectations concerning life's chances. Such selfconscious, hypersensitive parents, preoccupied with the ambigui-

Ecological Stress, Suppressed Hostility, Skin Color, and Black-White Male Blood Pressure: Detroit, 35 Psychosomatic Med. 276 (1973)[hereinafter cited as Harburg](suppressed hostility and darker skin "interact for high stress males and relate to high blood pressure"); Kiev, Psychiatric Disorders in Minority Groups, in Psychology and Race 416, 420-24 (P. Watson ed. 1973).

${ }^{25}$ See K. Clark, supra note 18 , at 82-84, 90. See generally W. Grier \& P. Cobbs, Black Rage 161 (1968)(paranoid symptoms are significantly more frequent among mentally ill blacks than among mentally ill whites); Special Populations Sub-Task Panel on Mental Health of Hispanic Americans, Report to the President's Commission on Mental Health 2, 10-11, 40 (1978).

${ }^{27}$ J. Martin \& C. Franklin, Minority Group Relations 3 (1979).

${ }^{28}$ See Joint Commission on Mental Health of Children, Social Change and the Mental Health of Children 99-100 (1973).

${ }^{29} \mathrm{Kiev}$, supra note 25 , at $416,420-21$. 
ty of their own social position, are unlikely to raise confident, achievement-oriented, and emotionally stable children.

In addition to these long-term psychological harms of racial labeling, the stresses of racial abuse may have physical consequences. There is evidence that high blood pressure is associated with inhibited, constrained, or restricted anger, and not with genetic factors, ${ }^{30}$ and that insults produce elevation in blood pressure.3i American blacks have higher blood pressure levels and higher morbidity and mortality rates from hypertension, hypertensive disease, and stroke than do white counterparts. ${ }^{32}$ Further, there exists a strong correlation between degree of darkness of skin for blacks and level of stress felt, a correlation that may be caused by the greater discrimination experienced by dark-skinned blacks. ${ }^{33}$

In addition to such emotional and physical consequences, racial stigmatization may damage a victim's pecuniary interests. The psychological injuries severely handicap the victim's pursuit of a career. The person who is timid, withdrawn, bitter, hypertense, or psychotic will almost certainly fare poorly in employment settings. An experiment in which blacks and whites of similar aptitudes and capacities were put into a competitive situation found that the blacks exhibited defeatism, half-hearted competitiveness, and "high expectancies of failure."34 For many minority group members, the equalization of such quantifiable variables as salary and entry level would be an insufficient antidote to defeatist attitudes because the psychological price of attempting to compete is unaffordable; they are "programmed for

${ }^{30}$ See Harburg, supra note 25, at 292.

${ }^{31}$ See Gentry, Effects of Frustration, Attack, and Prior Aggressive Training on Overt Aggression and Vascular Processes, $16 \mathrm{~J}$. Personality \& Soc. Psychology 718 (1970).

${ }^{32}$ See Harburg, supra note 25, at 294. See generally L.A. Times, Jan. 14, 1981, § I-A, at 4, col. 1 (discussing report of Children's Defense Fund)(black children more likely to be sick and to be without regular source of health care than white children; black children are three times as likely as white children to be labeled mentally retarded, and twice as likely to drop out of school before the twelfth grade).

${ }^{33}$ See Harburg, supra note 25, at 285-90.

${ }^{34}$ J. Martin \& C. Franklin, supra note 27, at 43. See G. Allport, supra note 11 , at 159. 
failure."35 Additionally, career options for the victims of racism are closed off by institutional racism ${ }^{36}$-the subtle and unconscious racism in schools, hiring decisions, and the other practices which determine the distribution of social benefits and responsibilities.

Unlike most of the actions for which tort law provides redress to the victim, racial labeling and racial insults directly harm the perpetrator. Bigotry harms the individuals who harbor it by reinforcing rigid thinking, thereby dulling their moral and social senses ${ }^{37}$ and possibly leading to a "mildly ... paranoid" mentality. ${ }^{38}$ There is little evidence that racial slurs serve as a "safety valve" for anxiety which would otherwise be expressed in violence. ${ }^{39}$

Racism and racial stigmatization harm not only the victim and the perpetrator of individual racist acts but also society as a whole. Racism is a breach of the ideal of egalitarianism, that "all men are created equal" and each person is an equal moral agent, an ideal that is a cornerstone of the American moral and legal system. ${ }^{40}$ A society in which some members regularly are sub-

${ }^{35} \mathrm{~J}$. Martin \& C. Franklin, supra note 27, at 4.

${ }^{36}$ See generally Report of the National Advisory Commission on Civil Disorders, supra note 11, ch. 7 ("Unemployment, Family Structure, and Social Disorganization"); Casas, Wampold \& Atkinson, The Categorization of Ethnic Stereotypes by University Counselors, 3 Hispanic J. Behavioral Sci. 75, 81 (1981)("[R]esults suggest that counselors have a constellation of stereotypes for each ethnic group; the confirmation of one stereotype in this constellation probably will tend to confirm the entire constellation.").

${ }^{37}$ See G. Allport, supra note 11, at 170-86, 371-84, 407-08.

${ }^{38}$ Allport, The Bigot in Our Midst, 40 Commonweal 582 (1944), reprinted in Anatomy of Racial Prejudice 161, 164 (G. deHuszar ed. 1946).

${ }^{39}$ See G. Allport, supra note 11, at 62, 252, 460-61, 467-72 (rejecting view of racist conduct as catharsis and arguing that racist attitudes themselves can be curtailed by law). But see R. Williams, The Reduction of Intergroup Tensions 41 (1947); Berkovitz, The Case for Bottling Up Rage, Psychology Today, July 1973, at 24; Magruder, Mental and Emotional Disturbance in the Law of Torts, 49 Harv. L. Rev. 1033, 1053 (1936)("[I]t would be unfortunate if the law closed all safety valves through which irascible tempers might legally blow off steam.").

${ }^{40}$ E.g., U.S. Const. amend. XIII, $\S 1$ (slavery prohibited); id. amend. XIV, $\S 1$ ("No state shall. . . deny to any person... the equal protection of the laws."); id. amend. XV, $\$ 1$ (right to vote not to be abridged by reason of race or color). 
jected to degradation because of their race hardly exemplifies this ideal. The failure of the legal system to redress the harms of racism, and of racial insults, conveys to all the lesson that egalitarianism is not a fundamental principle; the law, through inaction, implicitly teaches that respect for individuals is of little importance. Moreover, unredressed breaches of the egalitarian ideal may demoralize all those who prefer to live in a truly equal society, making them unwilling participants in the perpetuation of racism and racial inequality.

To the extent that racism contributes to a class system, ${ }^{41}$ society has a paramount interest in controlling or suppressing it. Racism injures the career prospects, social mobility, and inter-

See generally Brest, The Supreme Court, 1975 Term-Foreword: In Defense of the Antidiscrimination Principle, 90 Harv. L. Rev. 1 (1976); Dworkin, Social Science and Constitutional Rights: The Consequences of Uncertainty, 6 J. L. \& Educ. 3 (1977).

${ }^{41}$ It is difficult for the majority culture to accept responsibilty for the submergence of the minority culture, in part because the existence of a minority culture contradicts the larger society's formal values. See, e.g., G. Myrdal, An American Dilemma xliii (1944). The "American dilemma" is described by Myrdal as

the conflict between, on the one hand, the valuations preserved on the general plane which we shall call the 'American Creed,' where the American thinks, talks and acts under the influence of high national and Christian precepts, and, on the other hand, the valuations on specific planes of individual and group living, where personal and local interests; economic, social and sexual jealousies; considerations of community prestige and conformity; group prejudice against particular persons or types of people; and all sorts of miscellaneous wants, impulses and habits dominate his outlook.

Id.

Myrdal and other writers believe that the dilemma of minority group members cannot be altered significantly without changes in the way society views and treats minorities. See K. Clark, Prejudice and Your Child 8, 51 (1963); G. Myrdal, supra, at xliii. Clark, for example, writes that "self-hatred... cannot be understood in terms only of the minority group member's reaction to other members of his group. It is in fact a reflection of the Negro's reaction to all of the negative pressures that bombard him.... If there are to be significant changes...these changes can come only from positive and fundamental changes in the way in which the larger society views and treats the Negro." K. Clark, supra, at 51. 
racial contacts of minority group members. This, in turn, impedes assimilation into the economic, social, and political mainstream of society and ensures that the victims of racism are seen and see themselves as outsiders. ${ }^{42}$ Indeed, racism can be seen as a force used by the majority to preserve an economically advantageous position for themselves. ${ }^{43}$ But when individuals cannot or choose not to contribute their talents to a social system because they are demoralized or angry, or when they are actively prevented by racist institutions from fully contributing their talents, society as a whole loses.

Finally, and perhaps most disturbingly, racism and racial labeling have an even greater impact on children than on adults. The effects of racial labeling are discernible early in life; ${ }^{44}$ at a young age, minority children exhibit self-hatred because of their color, and majority children learn to associate dark skin with undesirability and ugliness. ${ }^{45} \mathrm{~A}$ few examples readily reveal the psychological damage of racial stigmatization on children. When presented with otherwise identical dolls, a black child preferred the light-skinned one as a friend; she said that the dark-skinned one looked dirty or "not nice."46 Another child hated her skin color so intensely that she "vigorously lathered her arms and face with soap in an effort to wash away the dirt." 47 She told the experimenter, "This morning I scrubbed and scrubbed and it came almost white." ${ }^{38}$ When asked about making a little girl out of

42 See S. Hayakawa, supra note 23, at 12, 78.

${ }^{4}$ See Krogman, An Anthropologist Looks at Race, 7 Intercultural Educ. News 1 (1945), reprinted in Anatomy of Racial Intolerance, supra note 38, at 20, 25; Mekeel, Race Relations, 27 Mental Hygiene 177 (1945), reprinted in Anatomy of Racial Intolerance, supra note 38, at 81, 87, 89 [hereinafter cited as Mekeel]; H. Powdermaker, Prejudice in the World Today, in Probing Our Prejudices (1944), reprinted in Anatomy of Racial Intolerance, supra note 38, at 27, 27; Redfield, What We Do Know About Race, 57 Sci. Monthly 193 (1943), reprinted in Anatomy of Racial Intolerance, supra note 38, at 7, 11, 13 [hereinafter cited as Redfield]. See generally O. Cox, supra note 17; W. Wilson, Power, Racism, and Privilege (1973).

4 See M. Goodman, supra note 24.

${ }^{45}$ See id. at 36-60. See also G. Allport, supra note 11, at 289-301.

${ }^{45} \mathrm{M}$. Goodman, supra note 24 , at 55 .

${ }^{47} \mathrm{Id}$. at 56.

${ }^{48} \mathrm{Id}$. at 58. 
clay, a black child said that the group should use the white clay rather than the brown "because it will make a better girl."49 When asked to describe dolls which had the physical characteristics of black people, young children chose adjectives such as "rough, funny, stupid, silly, smelly, stinky, dirty."so Three-fourths of a group of four-year-old black children favored white play companions; ${ }^{31}$ over half felt themselves inferior to whites..$^{52}$ Some engaged in denial or falsification. ${ }^{53}$

\section{B. The Harms of Racial Insults}

Immediate mental or emotional distress is the most obvious direct harm caused by a racial insult. Without question, mere words, whether racial or otherwise, can cause mental, emotional, or even physical ${ }^{54}$ harm to their target, especially if delivered in front of others ${ }^{55}$ or by a person in a position of authority. ${ }^{56}$ Racial insults, relying as they do on the unalterable fact of the victim's race and on the history of slavery and race discrimination in this country, have an even greater potential for harm than other insults.

Although the emotional damage caused is variable and depends on many factors, only one of which is the outrageousness of the insult, a racial insult is always a dignitary affront, a direct violation of the victim's right to be treated respectfully. Our moral and legal systems recognize the principle that individuals are entitled to treatment that does not denigrate their humani-

${ }^{49} I d$.

so Id.

${ }^{51}$ See id. at 83.

s2 See id. at 86.

${ }^{53}$ See id. at 60-73.

${ }^{54}$ E.g., Wilkinson v. Downton, [1897] 2 Q.B. 57 (defendant falsely told plaintiff her husband had had both legs broken in an accident; plaintiff suffered permanent physical harm).

ss E.g., Fisher v. Carrousel Motor Hotel, Inc., 424 S.W.2d 627 (Tex. 1967). See infra text accompanying notes 95-102.

${ }^{56}$ E.g., Alcorn v. Anbro Eng'g, Inc., 2 Cal. 3d 493, 468 P.2d 216, 86 Cal. Rptr. 88 (1970); Contreras v. Crown Zellerbach, Inc., 88 Wașh. 2d 735, 565 P.2d 1173 (1977)(en banc). See supra text accompanying notes 1-4; infra text accompanying notes 113-18. 
ty through disrespect for their privacy or moral worth. ${ }^{57}$ This ideal has a high place in our traditions, ${ }^{58}$ finding expression in such principles as universal suffrage, ${ }^{59}$ the prohibition against cruel and unusual punishment, ${ }^{60}$ the protection of the fourth amendment against unreasonable searches, ${ }^{61}$ and the abolition of slavery. ${ }^{62} \mathrm{~A}$ racial insult is a serious transgression of this principle because it derogates by race, ${ }^{63}$ a characteristic central to one's self-image.

The wrong of this dignitary affront consists of the expression of a judgment that the victim of the racial slur is entitled to less than that to which all other citizens are entitled. Verbal tags provide a convenient means of categorization so that individuals may be treated as members of a class and assumed to share all the negative attitudes imputed to the class. ${ }^{64}$ Verbal tags thus make it easier for their users to justify their own superior position with respect to others.65 Racial insults also serve to keep the victim

${ }^{57}$ Damages for mental or emotional distress are awarded in order to remedy invasion of the interest in dignity in actions for assault, battery, malicious prosecution, invasion of privacy, and alienation of affections. See D. Dobbs, Handbook on the Law of Remedies 528 (1973).

${ }^{58}$ See, e.g., L. Tribe, American Constitutional Law ch. 15 (1978)("Rights of Privacy and Personhood").

${ }^{59}$ See, e.g., id. ch. 13 ("Rights of Political Participation").

${ }^{6}$ U.S. Const. amend. VIII.

${ }^{61}$ U.S. Const. amend. IV.

62 U.S. Const. amend. XIII, § 1.

${ }^{63}$ See Sandalow, Racial Preferences in Higher Education: Political Responsibility and the Judicial Role, 42 U. Chi. L. Rev. 653, 668, 672 (1975)(classification on basis of color and other involuntary characteristics violates our conception of "the good society and... of the proper role of government").

${ }^{64}$ See F. Wertham, A Sign for Cain 89 (1966)(racial prejudice depersonalizes the victim, thereby rationalizing violence and inhumane treatment).

${ }^{65}$ See J. Kovel, supra note 20, at 132; C. Woodward, The Strange Career of Jim Crow xii (Galaxy ed. 1964); Equal Employment Opportunity Commission, Spanish-Surnamed American Employment in the Southwest 77 (1974)(use of terms such as "Spick" and "Greaser" facilitated Anglo assertion of cultural and economic superiority, as those so designated were not considered proper members of dominant society).

See also Famous Mexican Americans 54 (C. Newlon ed. 1972)(interview with Cesar Chavez):

[In Brawley] the cops wouldn't let us into Anglo Town, but there 
compliant. ${ }^{66}$ Such dignitary affronts are certainly no less harmful than others recognized by the law. Clearly, a society whose public law recognizes harm in the stigma of separate but equal schooling ${ }^{67}$ and the potential offensiveness of the required display of a state motto on automobile license plates, ${ }^{68}$ and whose private law sees actionable conduct in an unwanted kiss ${ }^{69}$ or the forcible removal of a person's hat, ${ }^{70}$ should also recognize the dignitary harm inflicted by a racial insult.

The need for legal redress for victims also is underscored by the fact that racial insults are intentional acts. The intentionality of racial insults is obvious: what other purpose could the insult serve? There can be little doubt that the dignitary affront of racial insults, except perhaps those that are overheard, is intentional and therefore most reprehensible. Most people today know that certain words are offensive and only calculated to wound. ${ }^{71}$ No other use remains for such words as "nigger," "wop," "spick," or "kike."

was a diner [with a "whites only" sign] right on the line, kind of, and everybody talked about how it was supposed to have beautiful hamburgers.... [Chavez] said, "Two hamburgers, please." The [counter] girl said, "What's the matter, can't you read? Damn dumb Mex."

She and her boyfriend laughed, and we ran out. Richard was cursing them, but I was the one who had spoken to them and I was crying. That laugh rang in my ears for twenty years. It seemed to cut us out of the human race.

${ }^{66}$ See Mekeel, supra note 43 , at 87,89 (racism as a means of protecting competitive advantages).

${ }^{67}$ See generally Brown v. Board of Educ., 347 U.S. 483 (1954). Brown turned, clearly, on the stigmatizing effect-the indignity or affront of separate schools-because by hypothesis the schools were "equal." See id. at 492.

${ }^{68}$ Wooley v. Maynard, 430 U.S. 705 (1977)(considerations of privacy and autonomy held to prevent New Hampshire from punishing citizens for putting tape over state motto "Live Free or Die" on license plates).

${ }^{69}$ See W. Prosser, Handbook of the Law of Torts, $\S 10$, at $36 \&$ n.85 (4th ed. 1971).

${ }^{70}$ See id. § 10, at 36 \& n.78.

7 See G. Allport, supra note 11, at 177 (When a speaker uses terms like "nigger," "spick," or "wop," "we can be almost certain that the speaker intends not only to characterize the person's membership, but also to disparage and reject him.")(emphasis in original). See generally S. Hayakawa, supra note 23, at 25 (racial and religious classifications serve no nondiscriminatory, predictive ends). 
In addition to the harms of immediate emotional distress and infringement of dignity, racial insults inflict psychological harm upon the victim. Racial slurs may cause long-term emotional pain because they draw upon and intensify the effects of the stigmatization, labeling, and disrespectful treatment that the victim has previously undergone. Social scientists who have studied the effects of racism have found that speech that communicates low regard for an individual because of race "tends to create in the victim those very traits of inferiority' that it ascribes to him." Moreover, "even in the absence of more objective forms of discrimination-poor schools, menial jobs, and substandard housing - traditional stereotypes about the low ability and apathy of Negroes and other minorities can operate as 'self-fulfilling prophecies." "73 These stereotypes, portraying members of a minority group as stupid, lazy, dirty, or untrustworthy, are often communicated either explicitly or implicitly through racial insults.

Because they constantly hear racist messages, minority children, not surprisingly, come to question their competence, intelligence, and worth. Much of the blame for the formation of these attitudes lies squarely on value-laden words, epithets, and racial names. ${ }^{74}$ These are the materials out of which each child "grows his own set of thoughts and feelings about race."75 If the majority "defines them and their parents as no good, inadequate, dirty, incompetent, and stupid," the child will find it difficult not to accept those judgments. ${ }^{76}$

Victims of racial invective have few means of coping with the harms caused by the insults. Physical attacks are of course forbidden. "More speech" frequently is useless because it may provoke only further abuse or because the insulter is in a position of authority over the victim. Complaints to civil rights organizations

${ }^{72}$ M. Deutsch, I. Katz \& A. Jensen, Social Class, Race and Psychological Development 175 (1968).

${ }^{73} \mathrm{Id}$.

74 See G. Allport, supra note 11, at vi; M. Goodman, supra note 24, at 73, 127-31, 135-36, 159-60, 163-64, 211, 232, 238-39; deHuszar, Preface, in Anatomy of Racial Intolerance, supra note 38, at 3, 3; Redfield, supra note 43, at 11.

75 M. Goodman, supra note 24, at 246.

${ }^{76}$ K. Keniston, All Our Children 33 (1977). 
also are meaningless unless they are followed by action to punish the offender." Adoption of a "they're well meaning but ignorant" attitude ${ }^{78}$ is another impotent response in light of the insidious psychological harms of racial slurs. When victimized by racist language, victims must be able to threaten and institute legal action, thereby relieving the sense of helplessness that leads to psychological harm and communicating to the perpetrator and to society that such abuse will not be tolerated, either by its victims or by the courts.

Minority children possess even fewer means for coping with racial insults than do adults. "A child who finds himself rejected and attacked . . . is not likely to develop dignity and poise. . . . On the contrary he develops defenses. Like a dwarf in a world of menacing giants, he cannot fight on equal terms."79 The child who is the victim of belittlement can react with only two unsuccessful strategies, hostility or passivity. Aggressive reactions can lead to consequences which reinforce the harm caused by the insults; children who behave aggressively in school are marked by their teachers as troublemakers, adding to the children's alienation and sense of rejection. ${ }^{80}$ Seemingly passive reactions have no better results; children who are passive toward their insulters turn the aggressive response on themselves; 81 robbed of confidence and motivation, these children withdraw into moroseness, fantasy, and fear. ${ }^{82}$

${ }^{7}$ See, e.g., J. Comer \& A. Poussaint, Black Child Care 226 (1976).

${ }^{78}$ See S. Hayakawa, supra note 23 , at 80.

${ }^{79} \mathrm{G}$. Allport, supra note 11 , at 139.

${ }^{80}$ See generally H. James, Children in Trouble 278 (1970); J. Kozol, Death at an Early Age (1967); Vredeval, Embarrassment and Ridicule, Nat'l Educ. A. J., Sept. 1963, at 17. Black teenagers have a one in ten chance of getting into trouble with the law and are five times more likely to be murdered than white teenagers. See L.A. Times, supra note 32. Black children are suspended from schools at twice the rate of white children. See id.

${ }^{81}$ See M. McDonald, Not by the Color of Their Skin 131 (1970).

${ }^{82}$ See generally K. Clark, supra note 18 , at 65 (sense of inferiority is the most serious race-related injury to black child); $M$. Deutsch, The Disadvantaged Child 106 (1968)(“ $[B]$ lack children tend to be more passive, more fearful and more diseuphoric than white.").

Deutsch has produced evidence to show that personality traits of defeatism and self-rejection in minority children are to a significant extent independent of 
It is, of course, impossible to predict the degree of deterrence a cause of action in tort would create. However, as Professor van den Berghe has written, "for most people living in racist societies racial prejudice is merely a special kind of convenient rationalization for rewarding behavior." 83 In other words, in racist societies "most members of the dominant group will exhibit both prejudice and discrimination," ${ }^{84}$ but only in conforming to social norms. ${ }^{85}$ Thus, "[W]hen social pressures and rewards for racism are absent, racial bigotry is more likely to be restricted to people for whom prejudice fulfills a psychological 'need.' In such a tolerant milieu prejudiced persons may even refrain from discriminating behavior to escape social disapproval."86 Increasing the cost of racial insults thus would certainly decrease their frequency. Laws will never prevent violations altogether, but they will deter "whoever is deterrable." 87

Because most citizens comply with legal rules, and this compliance in turn "reinforce[s] their own sentiments toward conformity," $" 88$ a tort action for racial insults would discourage such harmful activity through the teaching function of the law. ${ }^{89}$

income level. In a study comparing aptitude scores and self-image ratings among groups of low-income white children and similar black children, it was found that the latter had lower scores on aptitude tests and more negative self-images. See M. Deutsch, supra, at 106. Another study found that although I.Q. levels increased with education and prestige ratings of occupations of the parents of both white and black children, the gains were considerably less for black children. See id. at 295 . These studies seem to show that although poverty has a negative effect on a child's self-image and academic performance, the racial factor is even more significant. See also Kacser, Background Paper, in Subcomm. on Executive Reorganization and Government Research of the Senate Comm. on Government Operations, Government Research on the Problems of Children and Youth: Background Papers Prepared for the 1970-71 White House Conference on Children and Youth, 92d Cong., 1st Sess. 1, 15 (1971)(children who suffer from discrimination become convinced they are inferior and unworthy of help or affection, and respond by aggression, neurotic repression, withdrawal and fantasy).

${ }^{83} \mathrm{P}$. van den Berghe, Race and Racism 21 (2d ed. 1978).

B4 Id, at 20.

${ }^{85}$ See id. at 21.

${ }^{86} \mathrm{Id}$. at 20.

${ }^{87} \mathrm{G}$. Allport, supra note 11 , at 472 .

${ }^{88} \mathrm{R}$. Williams, supra note 39 , at 73 .

${ }^{89}$ See Olmstead v. United States, 277 U.S. 438, 485 (1928)(Brandeis, J., dissenting)(teaching role of the law); M. King, I Have a Dream: The Text of the 
The establishment of a legal norm "creates a public conscience and a standard for expected behavior that check overt signs of prejudice. ${ }^{90}$ Legislation aims first at controlling only the acts that express undesired attitudes. But "when expression changes, thoughts too in the long run are likely to fall into line."91 "Laws . . . restrain the middle range of mortals who need them as a mentor in molding their habits." tional arrangements in which exploitative behaviors are no longer reinforced, we will then succeed in changing attitudes [that underlie these behaviors]." ${ }^{93}$ Because racial attitudes of white Americans "typically follow rather than precede actual institutional [or legal] alteration," $" 94$ a tort for racial slurs is a promising vehicle for the eradication of racism.

\section{Legal Protection from Racial Insults}

The psychological, sociological, and political repercussions of the racial insult demonstrate the need for judicial relief. Part II(A) will examine the protection from racial insults afforded by current doctrine. The remainder of this section will consider the objections likely to be raised against an independent tort action for racial slurs. Part II(B) will examine objections arising from tort law, and Part II(C) will consider first amendment objections.

Speech Delivered August 28, 1963, at the Lincoln Memorial, Washington, D.C. (John Henry \& Mary Louise Bryant Found. 1963)(excerpted in Newsweek, Sept. 9,1963 , at 21)(law as agent of change in moral consciousness). See generally Andenaes, General Prevention-Illusion or Reality?, 43 J. Crim. L. Criminology \& Police Sci. 176, 179-81 (1952)(definition of concept of general prevention); Andenaes, The General Preventive Effects of Punishment, 114 U. Pa. L. Rev. 949, 950-51 (1966)(existence of a legal norm can habituate persons to obey the law without conscious fear or thought).

${ }^{90} \mathrm{G}$. Allport, supra note 11 , at 470 .

${ }^{91}$ Id.

${ }_{92}$ Id. at 439. See also G. Allport, Prejudice: A Problem in Psychological and Social Causation 4, Supp. Ser. No. 4, J. Soc. Issues (1950)(examination of prejudice as a mode of mental functioning).

${ }^{93} \mathrm{H}$. Triandis, The Impact of Social Change on Attitudes, in Attitudes, Conflict and Social Changes 132 (1972)(quoted in Katz, Preface, Toward the Elimination of Racism 8 (P. Katz ed. 1976)).

${ }^{94} \mathrm{G}$. Myrdal, supra note 41 , at 20 (fallacy of theory that law cannot change custom). 


\section{A. Current Legal Protection from Racial Insults}

Many of the arguments for a cause of action for racial insults are similar to the policies underlying causes of action for assault, battery, intentional infliction of emotional distress, defamation, and various statutory and constitutional causes of action. However, each of these doctrines has limitations which render it an unreliable means of redress for the victims of racial insults.

\section{Assault and Battery}

In Fisher v. Carrousel Motor Hotel, Inc., 95 the plaintiff, a mathematician attending a NASA convention in Texas, was accosted by a white restaurant employee while waiting in a cafeteria line. The employee snatched an empty plate from the plaintiff's hand and told him in a loud voice that he, a "Negro," could not eat in that cafeteria. ${ }^{96}$ The plaintiff did not allege that he was actually touched, or that he feared physical injury, but rather that he was "highly embarrassed and hurt" by the employee's actions in the presence of the plaintiff's associates..$^{97}$ Although the jury awarded him $\$ 900$, the trial judge denied any recovery. ${ }^{98}$ The Texas Court of Appeals affirmed, ${ }^{99}$ ruling that there had been neither a battery nor an assault ${ }^{100}$ and that under Texas law mental anguish without physical injury does not support a claim for damages in battery. The court reached this result even though the jury had found humiliation, indignity, and wanton disregard of the plaintiff's feelings.

The Texas Supreme Court reversed, finding that the plaintiff could recover under the rubric of battery because the waiter's

9s 424 S.W.2d 627 (Tex. 1967).

${ }^{95} I d$, at 628-29.

${ }^{n}$ Fisher v. Carrousel Motor Hotel, Inc., 414 S.W.2d 774, 775 (Tex. Civ. App. 1967).

${ }^{93} 414$ S.W.2d at 775.

${ }^{99}$ Id. at 776 (citing Harned v. E-Z Fin. Co., 151 Tex. 641, 254 S.W.2d 81 (1953)(refusing to permit tort action for intentional infliction of mental pain and anguish)).

${ }^{100} I d$. 
seizure of the plate supplied the required offensive touching. ${ }^{101}$ The court, further, held that because battery is a tort designed to protect dignity as well as physical security, the plaintiff was not required to show physical harm in order to recover damages. ${ }^{102}$

The holding in Fisher that the violent snatching of a plate from the plaintiff's hand constituted an offensive touching is not remarkable. ${ }^{103}$ But Fisher does indicate recognition by the Texas Supreme Court that racial insults and overt acts of discrimination can cause mental suffering and humiliation. Moreover, the facts of Fisher illustrate the inadequacies of the doctrines of assault and battery in protecting such a plaintiff. If the plate had not been snatched from plaintiff's hand, but he had been insulted until he put down the plate and left, or before he picked up the plate, he could not have recovered in battery. And because the employee's words did not put the plaintiff in fear of physical injury or touching, the plaintiff could not have recovered in assault. ${ }^{104}$

\section{Intentional Infliction of Emotional Distress}

Despite the ever-growing acceptance of intentional infliction of emotional distress as an independent tort, ${ }^{105}$ the perennial fear of a flood of fraudulent claims continues to mold the doctrine. The Second Restatement of Torts, for example, limits recovery to "severe emotional distress" caused by "extreme and outrageous conduct." 106 California permits recovery for physical injury to the plaintiff if the physical injury was foreseeable, ${ }^{107}$

101424 S.W.2d at 630.

${ }^{102} \mathrm{Id}$.

${ }^{103}$ See W. Prosser, supra note $69, \S 9$, at 34 (integrity of person includes "all those things which are in contact or connected with it").

${ }^{104}$ See also Anderson v. Pantages Theater Co., 114 Wash. 24, 194 P. 813 (1921)(black theatergoer told "none of [his] kind of people" could sit in box seats and physically pushed through lobby and out of theater).

${ }^{105}$ See W. Prosser, supra note 69, $\S 12$, at 62 .

${ }^{106}$ Restatement (Second) of Torts $\$ 46$ (1965). Some states have adopted the Restatement view. See, e.g., Grimsby v. Samson, 85 Wash. 2d 52, 60, 530 P.2d 291, 296 (1975).

107 State Rubbish Collectors Ass'n v. Siliznoff, 38 Cal. 2d 330, 336-37, 240 P.2d 282, 285 (1952)(en banc). 
but, in the absence of physical harm, requires that the invasion of plaintiff's mental tranquillity be "extreme and outrageous." 108 Utah requires that the distress be severe, that either the defendant have acted with the purpose of inflicting emotional distress or the distress be reasonably foreseeable, and that the defendant's actions be outrageous and intolerable. ${ }^{109}$ In Texas, the emotional distress must be accompanied by physical injury. 110

Yet, in addition to Contreras, ${ }^{111}$ courts on at least three occasions have upheld causes of action or verdicts for black plaintiffs in cases which stemmed in large part from racial insults. ${ }^{112}$ Two of these cases are from California. In the first, Alcorn $v$. Anbro Engineering, Inc., ${ }^{113}$ a black truck driver advised his supervisor that the supervisor had instructed another employee to violate union rules. The supervisor responded, "You goddam 'niggers' are not going to tell me about the rules. I don't want any 'niggers' working for me. I am getting rid of all the 'niggers' . . . you're fired." 14 Alcorn alleged that he had been neither rude nor insubordinate and that the supervisor's conduct was intentional,

${ }^{103}$ Alcorn v. Anbro Eng'g, Inc., 2 Cal. 3d 493, 498, 468 P.2d 216, 218, 86 Cal. Rptr. 88, 90 (1970).

${ }^{109}$ Samms v. Eccles, 11 Utah 2d 289, 293, 358 P.2d 344, 347 (1961).

"10 Harned v. E-Z Fin. Co., 151 Tex. 641, 254 S.W.2d 81 (1953).

III See supra text accompanying notes 1-4.

112 The early case law of intentional infliction is indicative of the lack of sensitivity courts have shown to the feelings of black people. For example, an early Texas case held that the plaintiff, a white woman, stated a cause of action for intentionally inflicted mental distress when the defendant came into her yard, knowing she was pregnant, and assaulted two blacks, using profane language and causing the plaintiff to miscarry. The court cited an earlier case in which the defendant had shot and killed a dog in the presence of the plaintiff, causing the woman to miscarry. Hill v. Kimball, 76 Tex. 210, 215-16, 13 S.W. 59, 59-60 (1890)(citing Renner v. Canfield, 36 Minn. 40, 30 N.W. 435 (1886)). The Texas opinion contains no mention of any right of action on the part of the blacks. See also Richardson v. State, 23 Ala. App. 260, 123 So. 283 (1929)(black defendant charged with "assault to rape;" court said, "What would be a... mere assault as between persons of the same or similar social standing would become of much graver moment as between persons of a different social status and of different races.").

1132 Cal. 3d 493, 468 P.2d 216, 86 Cal. Rptr. 88 (1970).

${ }^{114} \mathrm{Id}$. at $496-97,468$ P.2d at 217, 86 Cal. Rptr. at 89 . The firm's secretary later "ratified" the act by firing the plaintiff. Id. at $497,468 \mathrm{P} .2 \mathrm{~d}$ at $217,86 \mathrm{Cal}$. Rptr. at 89. 
malicious, and intended to cause humiliation and mental anguish. The court held these allegations sufficient to state a cause of action for "extreme and outrageous" intentional infliction of emotional distress. ${ }^{115}$ In so holding, the court emphasized the employee-employer relationship between the parties, ${ }^{116}$ the plaintiff's allegation of particular susceptibility to emotional distress, ${ }^{117}$ and developments in social consciousness that render the term "nigger" particularly offensive. ${ }^{118}$

In the second case, Agarwal v. Johnson, ${ }^{119}$ the plaintiff, a native of East India, sued his former employer and two of his former supervisors for repeated harassment. The plaintiff testified that on one occasion one of his supervisors had said to him, "You black nigger, member of an inferior race, get out and do it." 120 The jury awarded the plaintiff general and punitive damages, and the state supreme court held that the evidence was sufficient to support the verdict for intentional infliction of emotional distress. ${ }^{121}$

Because the question of whether the defendant's conduct is "extreme and outrageous" must be answered on a case-by-case basis, and because the racial insults in these two cases were linked with other reprehensible conduct, including the unjustified termination of the plaintiff's employment, it is impossible to know whether the racial slurs were decisive factors in Alcorn and Agarwal. Courts always have been extremely reluctant to impose liability on the basis of words alone. ${ }^{122}$ However, the Alcorn

${ }^{115}$ Id. at 498,468 P.2d at $218,86 \mathrm{Cal}$. Rptr. at 90 . See supra text accompanying notes $107-08$.

${ }^{116}$ Id. at 498 \& n.2, 468 P.2d at $218 \&$ n.2, 86 Cal. Rptr. at $90 \&$ n.2 (status as an employee entitles plaintiff to greater degree of protection than a stranger).

117 Id. at 498 \& n.3, 468 P.2d at 218 \& n.3, 86 Cal. Rptr. at $90 \&$ n.3. The court adverted to the susceptibility of blacks to emotional distress from discriminatory conduct. Id. at 498 n.3, 468 P. $2 \mathrm{~d}$ at 218 n.3, 86 Cal. Rptr. at 90 n. 3 (citing Colley, Civil Actions for Damages Arising Out of Violations of Civil Rights, 17 Hastings L.J. 189, 201 (1965-66)). See infra text accompanying notes 221-22.

${ }^{118} 2$ Cal. 3d at 499 n.4, 468 P.2d at 219 n.4, 86 Cal. Rptr. at 90 n.4.

11925 Cal. 3d 932, 603 P.2d 58, 160 Cal. Rptr. 141 (1979).

${ }^{120} \mathrm{Id}$. at 941, 603 P.2d at 64, $160 \mathrm{Cal}$. Rptr. at 146.

${ }^{121}$ Id. at 947,603 P.2d at 67, 160 Cal. Rptr. at 150 .

${ }^{122}$ See W. Prosser, supra note $69, \S 10$, at $39-40$. 
court left open the question whether "mere insulting language, without more," could constitute "extreme outrage,"123 and the Agarwal court stated that the plaintiff "presented substantial evidence that [one supervisor's] use of the racial epithet was outrageous."124

In Wiggs $v$. Courshon, ${ }^{125}$ the plaintiffs, a recent law graduate and his family, became engaged in an argument with a waitress serving them in the restaurant of the hotel in which they were staying while on vacation. The waitress said, "You can't talk to me like that, you black son-of-a-bitch. I will kill you."126 Later, she was overheard shouting repeatedly, "[T]hey are nothing but a bunch of niggers."127 The case was tried on the theory of assault, although the plaintiff also alleged mental anguish and emotional distress. At the close of the evidence, however, it was apparent that the plaintiffs were never reasonably in fear of physical injury. And under the controlling Florida law, plaintiffs may recover for intentional infliction of emotional distress only when that distress is "severe." 128

Nevertheless, the federal district court upheld the jury's verdict for the plaintiff on the basis of dictum in the controlling Florida Supreme Court decision, Slocum v. Food Fair Stores of Florida, Inc. ${ }^{129}$ In that case, the plaintiff, a customer in a supermarket, asked a clerk the price of an item the clerk was marking. The clerk replied, "If you want to know the price, you'll have to find out the best way you can ... you stink to me."130 The plaintiff sought to recover for her ensuing emotional distress and "heart attack and aggravation of pre-existing heart disease."131 The court held that these allegations did not state a cause of action because the "unwarranted intrusion [into the plaintiff's mental tranquillity] must be calculated to cause 'severe emotional

${ }^{123} 2$ Cal. 3d at 499 \& n.5, 468 P.2d at 219 \& n.5, 86 Cal. Rptr. at 91 \& n.5. ${ }^{124} \mathrm{Id}$. at 947,603 P.2d at $67,160 \mathrm{Cal}$. Rptr. at 150 .

12s 355 F. Supp. 206 (S.D. Fla. 1973).

${ }^{126} \mathrm{Id}$. at 208.

127 Id.

${ }^{128}$ Slocum v. Food Fair Stores of Florida, Inc., 100 So. 2d 396 (Fla. 1958).

${ }^{129} I d$.

${ }^{130} \mathrm{Id}$. at $396-97$.

131 Id. at 396. 
distress' to a person of ordinary sensibilities, in the absence of special knowledge or notice." ${ }^{132}$ Nevertheless, the court noted that a "broader rule has been developed" for "offense reasonably suffered by a patron from insult by a servant or employee of a carrier, hotel, theater, ... [or] telegraph office." ${ }^{133}$ It was this dictum on which the Wiggs court grounded liability. ${ }^{134}$

Wiggs exemplifies the shortcomings of the doctrine of intentional infliction of emotional distress as a means for redressing racial insults. The jury was eager to find for the plaintiffs, awarding them $\$ 25,000$ in compensatory and punitive damages. ${ }^{135}$ But the judge was forced to ground liability on dictum which had never before been cited in the state ${ }^{136}$ and which had not been suggested to the court by either party. ${ }^{137}$ Most importantly, had the plaintiff's dispute developed with another customer rather than an employee, no recovery would have been possible. The injury arguably is lesser when the perpetrator is simply another customer, but in Wiggs the plaintiffs' humiliation before the other diners would have been just as great, and their vacation just as ruined.

Of course, the plaintiffs did win in Contreras, Alcorn, Agarwal, and Wiggs. But in at least two recent cases ${ }^{138}$ based substantially on racial insults, the plaintiffs lost because the defendants' actions were not sufficiently culpable. In Irving $v$. J.L. Marsh, Inc., ${ }^{139}$ the plaintiff, a black architecture student, returned certain merchandise he had purchased to the defendant's store. In order to obtain a refund, he was required to sign a slip on the top of which defendant's employee had written, "Arrogant

${ }^{132} I d$. at 398.

${ }^{133} \mathrm{Id}$.

134355 F. Supp. at 209-10 \& n.3.

${ }^{135} \mathrm{Id}$. at 210 . The trial judge reduced this amount to $\$ 2500$. Id. at 211 .

${ }^{136} \mathrm{Id}$. at 209.

${ }^{137}$ Id.

${ }^{138}$ See also De La Ysla v. Public Theatres Corp., 82 Utah 598, 26 P.2d 818 (1933)(Filipino plaintiff alleged that theater would not permit him to sit in seats on lower floor for which he had purchased tickets; held, action sounds in contract, not tort, and if plaintiff wins on merits he is entitled to judgment for purchase price of tickets, $\$ 1.40$ ).

13946 Ill. App. 3d 162, 360 N.E.2d 983 (1977). 
Nigger refuses exchange-says he doesn't like products."140 The court held that such conduct was not "sufficiently severe"141 for the plaintiff to recover. Similarly, in Bradshaw v. Swagerty, ${ }^{142}$ the plaintiff, a young black man, had been invited to the office of the defendant, a lawyer, to discuss accounts allegedly owed the defendant's client by the plaintiff and his brother. The conversation became heated, and the plaintiff alleged that the defendant called him "nigger," a claim that the defendant apparently did not deny. ${ }^{143}$ The court held that such epithets are "'mere insults' of the kind which must be tolerated in our roughened society" and affirmed summary judgment for the defendant. ${ }^{144}$

The Irving court appeared sympathetic to the plaintiff, noting that "[w]hile the derogatory and highly offensive character of defendant's actions is not condoned by this court, the law, in its present state, does not permit recovery for the humiliation plaintiff was forced to endure."145 Arguably, then, the court's failure to impose liability resulted from the ever-present judicial fear of encouraging fraudulent claims and a flood of litigation. The court's reluctance to redress the plaintiff's injuries is symptomatic of the inadequacy of the tort for intentional infliction of emotional distress in such cases. One of the comments in the Second Restatement of Torts section on intentional infliction states in part, "The liability clearly does not extend to mere insults, indignities, threats, annoyances, petty oppressions, or other trivialities. ... There must still be freedom to express an unflattering opinion, and some safety valve must be left through which irascible tempers may blow off relatively harmless steam."146

${ }^{140} I d$. at 164,360 N.E.2d at 985 .

${ }^{141} I d$. at 167,360 N.E.2d at 986.

1421 Kan. 2d 213, 563 P.2d 511 (1977).

${ }^{143}$ See id. at 214, 563 P.2d at 513 ("Defendant admitted using the term 'bastard,' but denied that he 'directly' called plaintiff a 'nigger.' ").

${ }^{144}$ Id. at 216, 563 P.2d at 514 (quoting Restatement (Second) of Torts $\$ 46$ comment d (1965)). See infra note 146 \& accompanying text.

14s 46 Ill. App. 3d at 167, 360 N.E.2d at 986 (citing Slocum v. Food Fair Stores of Florida, Inc., 100 So. 2d 396 (Fla. 1958)).

${ }^{146}$ Restatement (Second) of Torts $\S 46$ comment d (1965). Comment d states in part:

The liability clearly does not extend to mere insults, indignities, threats, annoyances, petty oppressions, or other trivialities. The rough 
What courts have thus far failed to recognize is that racial insults are in no way comparable to statements such as, "You are a God damned woman and a God damned liar," which the Restatement gives as an example of a "mere insult." 147 Racial insults are different qualitatively because they conjure up the entire history of racial discrimination in this country. ${ }^{148}$ No one would argue that slavery can be characterized as a "petty oppression" or lynch mobs as "mere annoyances," but thus far courts generally have not recognized the gravity of racial insults within the rubric of the tort of intentional infliction of emotional distress. Only an independent tort for racial insults can fully take into account the unique, powerfully evocative nature of racial insults and the insidious harms they inflict.

\section{Defamation}

In both Irving ${ }^{149}$ and Bradshaw, ${ }^{150}$ the plaintiffs also pled a cause of action in defamation, and both lost on that claim. In neither case did the plaintiff allege special damages, and thus both the Irving ${ }^{151}$ and Bradshaw ${ }^{152}$ courts ruled that the words

edges of our society are still in need of a good deal of filing down, and in the meantime plaintiffs must necessarily be expected and required to be hardened to a certain amount of rough language, and to occasional acts that are definitely inconsiderate and unkind. There is no occasion for the law to intervene in every case where some one's [sic] feelings are hurt. There must still be freedom to express an unflattering opinion, and some safety valve must be left through which irascible tempers may blow off relatively harmless steam.

${ }^{147}$ See id. illustration 4 (such an insult, made over the phone to a telephone operator, which causes severe emotional distress, is "not so outrageous or extreme" as to render the speaker liable).

${ }^{148}$ See Bradshaw, 1 Kan. 2d at 215, 563 P.2d at 514 ("The term 'nigger' is one of insult, abuse and belittlement harking back to slavery days.").

149 See supra text accompanying notes 139-41.

150 See supra text accompanying notes 142-44.

${ }^{151} 46$ Ill. App. 3d at 165-66, 360 N.E.2d at 985 . The court also held that the word "nigger" did not impute to the plaintiff an inability to perform the duties of his chosen profession, one of the categories of defamation per se in Illinois. 46 Ill. App. 3d at 166, 360 N.E.2d at 985.

1521 Kan. $2 d$ at $214-15,563$ P.2d at 514. 
alleged did not fit into any of the recognized categories of defamation per se. The Bradshaw court, however, did note that "[t]he term 'nigger' is one of insult, abuse and belittlement harking back to slavery days. Its use is resented, and rightly so. It nevertheless is not within any category recognized as slanderous per se."153 Yet, interestingly, in at least three older cases, white plaintiffs were permitted to sue for defamation defendants who indicated that the plaintiffs were black. ${ }^{54}$

It should not be surprising that defamation has failed to protect the victims of racial insults. "Defamation" is "an invasion of the interest in reputation and good name,"155 although the law protects only victims of false defamatory statements. In contrast, the maker of a racial insult invades the victim's interest in emotional tranquillity. A third party who learned that a person was the victim of a racial insult, but did not know the victim, would probably conclude that the victim is a member of a particular racial minority. But if this conclusion is true, the victim cannot recover because no falsehood has occurred.156 And whether or not the conclusion is true, it is not desirable that the law view

${ }^{153} \mathrm{Id}$. at 215,563 P.2d at 514. Cf. W. Prosser, supra note $69, \S 111$, at 737 ("It must be confessed at the beginning that there is a great deal of the law of defamation which makes no sense."). See also Mitchell v. Tribune Co., 343 Ill. App. 446, 99 N.E.2d 397 (1951), cert. denied, 342 U.S. 919 (1952)(upholding dismissal of complaint alleging that newspaper called plaintiff "Chink" and "Negro" on ground that such did not constitute defamation per se and special damages were not alleged; plaintiff's race not indicated); Davis v. Meyer, 115 Nebr. 251, 212 N.W. 435 (1927)(holding that calling plaintiff "half-breed Mexican" is not defamatory).

is4 Jones v. R.L. Polk \& Co., 190 Ala. 243, 67 So. 577 (1915); Natchez Times Publishing Co. v. Dunigan, 221 Miss. 320, 72 So. 2d 681 (1954); Bowen v. Independent Publishing Co., 230 S.C. 509, 96 S.E.2d 564 (1957). See also AfroAmerican Publishing Co. v. Jaffe, 366 F.2d 649 (D.C. Cir. 1966)(held, white plaintiff defamed by black newspaper which described plaintiff as bigoted); Sharp v. Bussey, 137 Fla. 96, 187 So. 779 (1939)(upholding jury verdict, although limiting damages to $\$ 10,000$, against defendant who told others that white plaintiff had danced with black women); Axton Fisher Tobacco Co. v. Evening Post Co., 169 Ky. 64, 183 S.W. 269 (1916)(held, allegation that newspaper falsely reported that plaintiff employed black foreman to supervise white female employees stated cause of action in libel).

$195 \mathrm{~W}$. Prosser, supra note $69, \S 111$, at 737.

${ }^{156}$ See id. § 116, at 796-99. 
membership in a racial minority as damaging to a person's reputation, even if some members of society consider it so.

\section{Constitutional and Statutory Provisions}

Victims of racial insults who have sued state officials under section $1983^{157}$ have achieved differing results. In Harris $v$. Har$v e y,{ }^{158}$ for example, a black police officer sued a white judge for a "racially motivated campaign to discredit and damage"159 the police officer and have him relieved of his job. As part of his extraordinary campaign, ${ }^{160}$ the judge had referred to the officer as a "black bastard." 161 In affirming the jury's award of $\$ 260,000$ in compensatory and punitive damages and the trial court's award of attorney's fees, the Seventh Circuit Court of Appeals held that "such an intentional tort inspired by racial animus and perpetrated under color of state law constitutes a denial of equal protection."162 The court also ruled that the judge's use of the power and prestige of his office brought his acts under color of law, even though the judge's campaign was not within the scope of his judicial duties, and thus the defense of judicial immunity was unavailable. ${ }^{163}$

In contrast, in Johnson v. Hackett ${ }^{164}$ a district court ruled that the complaint failed to state a claim under section 1983. The plaintiff alleged that on a certain evening two uniformed police officers on patrol threatened to fight a group of blacks and said that they would return later that evening. The officers did return, one asking, "Where are the night fighters?," the other asking, "What's a dead nigger anyway?"165 The next day, with the two officers again in uniform and on patrol, one of the officers called the plaintiff a "Chinese nigger." The plaintiff responded "with a

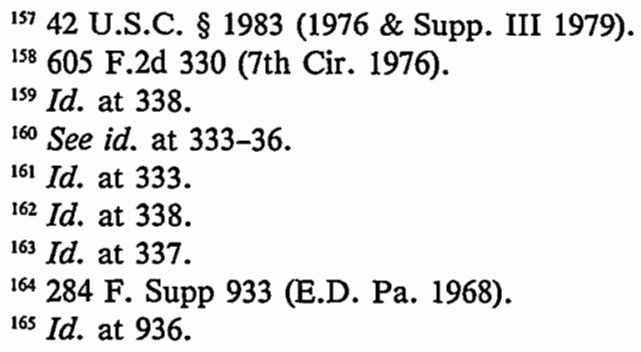


similar expression, but without racial overtones."166 A third officer then asked the two officers if they had provoked the expression. After they replied that they had not, the third officer arrested the plaintiff for disorderly conduct.

The court held that there had been no infringement of the right to freedom from unlawful arrest and that the plaintiff's other alleged right, the "right to dignity," was not constitutionally protected. ${ }^{167}$ The court also reached the highly questionable conclusion that the two police officers had not acted under color of law because they were not authorized to call anyone insulting names. Reasoning that "the purely personal nature of the offer [to fight] is emphasized by the allegation that, before the challenge was issued, [the officer] removed his gun belt, laying aside, as it were, the symbol or 'pretense' of police authority,"168 the court concluded, "It is the nature of the act performed, not the clothing of the actor or even the status of being on duty, or off duty, which determines whether the officer has acted under color of law." 169

The requirements of section 1983 -that the right infringed be granted by the federal constitution or laws and that the official be acting under color of law - present formidable hurdles for victims of racial insults. ${ }^{170}$ The campaign of racial vilification in Harris $^{171}$ was so extreme and unlikely to be repeated that one must conclude that the outcome in Johnson, not Harris, will emerge as the usual result.

If this is the case, it will be in sharp contrast to other areas in which the law increasingly is recognizing that the use of racial language by government officials is intolerable. The United States

${ }^{165} I d$.

${ }^{167}$ Id. at $938-40$. The plaintiff did not allege a denial of equal protection.

${ }^{163}$ Id. at 937 (quoting Screws v. United States, 325 U.S. 91, 111 (1945)). It is telling that the court considered the officer's gun, rather than his uniform or badge, or the fact that he was on duty, as "the symbol... of police authority." ${ }^{169} I d$.

170 See generally El-Em Band of Pomo Indians v. 49th Dist. Agricultural Fair Ass'n, 359 F. Supp. 1044 (N.D. Cal. 1973)("right [of Indian tribe] to be free from being made a public object of ridicule through use of a symbol which derogatorily depicts their race" not guaranteed by federal constitution).

17 See supra note 160 \& accompanying text. 
Supreme Court has found constitutional error in a contempt citation issued against a black witness who refused to answer questions until the adverse attorney addressed her as "Miss Hamilton" rather than "Mary." 172 And the Minnesota Supreme Court has held:

We cannot regard use of the term 'nigger' in reference to a black youth as anything but discrimination against that youth based on his race. ... When a racial epithet is used to refer to a [black] person . . . an adverse distinction is implied between that person and other persons not of his race. The use of the term 'nigger' has no place in the civil treatment of a citizen by a public official. We hold that use of this term by police officers coupled with all of the other uncontradicted acts described herein constituted discrimination because of race. ${ }^{173}$

Similarly, courts and administrative bodies have imposed duties to avoid racial language on prison officials, ${ }^{174}$ police officers, ${ }^{175}$ and school boards. ${ }^{176}$ In 1980 the San Francisco Civil Service

${ }^{172}$ Ex parte Hamilton, 376 U.S. 650 (1964)(per curiam), rev'g 275 Ala. 574, 156 So. 2d 926 (1963).

As this Article was going to press, the California Supreme Court ruled that a judge's use of the racial terms "jig," "dark boy," "colored boy," "nigger," "coon," "Amos and Andy," and "jungle bunny," in reference to blacks, and "cute little tamale," "spick," and "bean," in reference to Hispanics, constituted conduct "prejudicial to the administration of justice that brings the judical office into disrepute." Judge Mosk, dissenting, said that although he was morally offended by the judge's remarks, the remarks fell within the judge's right to freedom of expression. See San Francisco Chronicle, May 21, 1981, at 1, col. 4.

${ }^{173}$ City of Minneapolis v. Richardson, 307 Minn, 80, 82-83, 239 N.W.2d 197, 200 (1976)(crowd of people observed police making arrest; police used dogs to disperse crowd; dog bit hand of man next to black youth, then leapt at black youth who struck it with rolled-up poster; black youth arrested, dragged face down to police car, called "nigger" by police). See also City of Minneapolis v. State, 310 N.W.2d 485, 487 (Minn. S. Ct. 1981)(Minnesota antidiscrimination statute prohibits police officer calling white person "nigger lover").

${ }_{174}$ See Holt v. Hutto, 363 F. Supp. 194, 205, 214 (E.D. Ark. 1973).

${ }^{175}$ See Allen v. City of Mobile, 331 F. Supp. 1134, 1150 (S.D. Ala. 1971), aff'd, 466 F.2d 122 (5th Cir. 1972)(per curiam), cert. denied, 412 U.S. 909 (1973). ${ }^{176}$ See Telephone Interview with Kris Banter, Administrator, Seattle School 
Commission enacted a policy under which city officials and employees could be demoted, suspended, or dismissed for uttering racial slurs while on duty. ${ }^{177}$ And in at least one case a jury has found government discrimination especially intolerable. In Haddix $v$. Port of Seattle, ${ }^{178}$ a case brought under a state antidiscrimination statute against a government agency for four years of abusive treatment at the hands of a white foreman, ${ }^{179}$ the jury awarded the plaintiff $\$ 200,000$, rather than the $\$ 145,000$ the plaintiff had requested. One juror said, "We set the sum of $\$ 200,000$ as a statement that race discrimination is wrong, and that the port is a public corporation and should be in the forefront of fighting discrimination." 180

Despite this trend, victims of racial slurs have achieved mixed results when suing persons or entities other than government officials under various state or federal civil rights laws. Some plaintiffs have prevailed under state antidiscrimination statutes. For example, in Imperial Diner, Inc. v. State Human Rights Appeal Board, ${ }^{181}$ a restaurant owner had told a waitress that she thought she was something special, "Just like all the other f----

Board (May 9, 1982); Memorandum, Seattle School Board, Introduction of a New Policy: Acts of Hostility or Defamation (June 27, 1979)(copy on file with the author); Letter from Charles Z. Smith, attorney at law, to Mrs. Patt Sutton, Board of Directors, Seattle Public Schools (May 10, 1978) (on file with the Harvard Civil Rights-Civil Liberties Law Review).

177 L.A. Times, Aug. 20, 1980, § I, at 1, col. 1. The guideline has been adopted by at least three dozen San Francisco agencies and school districts. Interview with Al Walker, Secretary, San Francisco Civil Service Commission, in San Francisco, Calif., Oct. 9, 1980. See also Thompson v. City of Minneapolis, 300 N.W.2d 763 (Minn. S. Ct. 1980)(upholding dismissal of city employee, under city civil service commission rule prohibiting language "wantonly offensive" to public, for making subsequently published racist remarks in presence of newspaper reporter).

${ }^{178}$ No. 840149, King Co. (Wash.) Super. Ct. (July 31, 1978). See Seattle Times, Aug. 1, 1978, § A, at 1, col. 1.

179 The plaintiff was subjected to "abusive racial language, humiliating treatment and inferior work assignments." The foreman had stated, "As long as I am the foreman out here, white is right," and called the plaintiff a "nigger." See Seattle Times, Aug. 1, 1978, § A, at 11, col. 1.

${ }^{100} I d$. at 1 , col. 1 .

${ }^{181} 52$ N.Y.2d 72, 417 N.E.2d 525, 436 N.Y.S.2d 231 (1980). 
ing Jewish broads around here." "182 The owner repeatedly refused to apologize. The New York Court of Appeals affirmed the State Division of Human Rights ruling that the petitioner discriminated against the waitress by reviling her religion in a matter related to her working conditions and enforced the Division's award of $\$ 500$ to the waitress for " shock, humiliation, and outrage." "183

Other victims of racial slurs, however, have been less successful in their efforts to recover against private persons and entities under state and federal laws. An attempt to invoke section $1981^{184}$ and the Civil Rights Act of $1964^{185}$ to obtain relief failed in Howard v. National Cash Register Co. ${ }^{186}$ In that case fellow employees had used the word "nigger" and other race-related language in plaintiff's presence. ${ }^{187}$ Although Title VII of the Act forbids an employer "to limit . . . his employees . . . in any way which would deprive or tend to deprive any individual of employment opportunities or otherwise adversely affect his status as employee, because of such individual's race,", ${ }^{188}$ the court found that the racial abuse did not constitute employment discrimination. ${ }^{189}$

${ }^{182} \mathrm{Id}$. at 76,417 N.E.2d at 527, 436 N.Y.S.2d at 233.

${ }^{183} \mathrm{Id}$. at 76-77, 417 N.E.2d at 528, 436 N.Y.S.2d at 233. See also Browning v. Slenderella Sys., 54 Wash. 2d 440, 341 P.2d 859 (1959)(en banc)(reducing salon's refusal to serve a black woman constitutes discrimination); Anderson v. Pantages Theatre Co., 114 Wash. 24, 194 P. 813 (1921)(theater's refusal to admit black attorney to show for which he held tickets constitutes discrimination).

${ }^{184} 42$ U.S.C. $\$ 1981$ (1976).

${ }^{185}$ Id. $\S \S 2000$ a to $2000 \mathrm{~h}-6$ (1976 \& Supp. III 1979).

186388 F. Supp. 603 (S.D. Ohio 1975).

${ }^{187} \mathrm{Id}$. at 605 .

18842 U.S.C. $\S 2000 \mathrm{e}-2(\mathrm{a})(2)$ (1976).

189388 F. Supp. at 606 . The Howard court apparently felt that it was powerless to redress the alleged injury:

The language of the factory and the language of the street have long included words such as "Greaser", "Dago", and "Spick", and "Kike" and "Chink" as well as "Nigger". In the past three years we have even adopted as a part of our folk lore a character who is prejudiced and biased aganst all persons other than of his own neighborhood, religion and nationality. We refer to such people now as "Archie Bunkers." The Archie Bunkers of this world, within limitations, still may assert their biased 
And in Irving, ${ }^{190}$ the court held that the plaintiff could not recover under an Illinois constitutional provision prohibiting "communications that portray criminality, depravity or lack of virtue in, or that incite violence, hatred, abuse or hostility toward, a person or group of persons by reason of or by reference to religious, racial, ethnic, national or regional affiliation,"191 because that provision does not grant a private right of action. ${ }^{192}$

Although it is correct to say, as did the Minnesota Supreme Court, ${ }^{193}$ that the use of a racial insult against a member of a minority group is race discrimination, apparently no court has found discrimination solely on the basis of a single racial insult. Courts appear unwilling to impose the vast liability and opprobrium that follow a finding of violation of federal and state antidiscrimination laws on the makers of racial insults. Recovery often is stymied further by the requirement, incorporated in many of these statutes, that there be some relationship between the parties, such as a contractual ${ }^{194}$ or employment relationship. ${ }^{195}$ And, of course, it is reasonable to assume that

view. We have not yet reached the point where we have taken from individuals the right to be prejudiced, so long as such prejudice did not evidence itself in discrimination. This Court will secure plaintiff against discrimination; no court can secure him against prejudice.

Id. The court also noted "without comment the following observation" : "Against a large part of the frictions and irritations and clashing of temperaments incident to participation in a community life, a certain toughening of the mental hide is a better protection than the law ever could be." Id. (quoting Magruder, supra note 39 , at 1053).

${ }^{190}$ See supra text accompanying notes 139-41 \& 149-52.

${ }^{19 !}$ Ill. Const. art. I, $\S 20$. The provision was derived from the criminal libel statute held constitutional in Beauharnais v. Illinois, 342 U.S. 250 (1952).

19246 Ill. App. 3d at 165, 360 N.E.2d at 984. See also State Div. of Human Rights v. McHarris Gift Center, 71 A.D.2d 813, 419 N.Y.S.2d 405 (1979), aff'd, 52 N.Y.2d 813, 418 N.E.2d 393, 436 N.Y.S.2d 878 (1980)(mem.)(store's sale of novelties which demean persons of Polish extraction held not violative of New York antidiscrimination law).

${ }^{193}$ See supra text accompanying note 173.

${ }^{194}$ E.g., 42 U.S.C. $\S 1981$ (1976).

${ }^{195}$ E.g., id. $\S 2000$ e to 2000 e-14 (1976 \& Supp. III 1979).

As this Article was going to press, a private individual was convicted under a recently enacted New York statute prohibiting harassment by reference to race 
there is a substantial amount of variation in the protection afforded by state antidiscrimination laws. Such problems would be eliminated by an independent tort for racial insults because it would protect all victims from racial insults regardless of the jurisdiction or the relationship between the parties.

\section{B. Objections to a Tort for Racial Insults}

Recognition of a tort for racial insults undoubtedly will face all the objections voiced whenever courts choose to protect a previously unrecognized interest - the difficulty of measuring and apportioning damages, the potential for fraudulent claims, and the prospect of a flood of litigation. ${ }^{196}$ Such objections, however, need not impede the recognition of a new tort. The now-recognized torts of invasion of privacy, ${ }^{197}$ intentional infliction of emotional distress, ${ }^{198}$ and compensation for prenatal injuries $^{199}$ are illustrations of new causes of action that were fashioned to cope with substantial injuries that did not fit into an existing category. As Dean Prosser has observed, "[T]he mere fact that the claim is novel will not of itself operate as a bar to the remedy."200

or ethnicity. The harassment in that case was as anti-Semitic slur made in an argument between neighbors. See N.Y. Times, May 14, 1982, at B2, col. 1. The statute is Act of July $31,1981,1981$ N.Y. Laws ch. $870, \S 1$ (codified at N.Y. Civ. Rights Law § 40-c(3) (McKinney Supp. 1981).

${ }^{196}$ See W. Prosser, supra note 69, § 1, at 3; Smith, Torts Without Particular Names, 69 U. Pa. L. Rev. 91 (1921). See generally Ruiz v. Bertolotti, 37 Misc. 2d 1067, 236 N.Y.S.2d 854 (1962)(upholding complaint in prima facie tort which alleged that defendants threatened physical harm to plaintiffs' family if plaintiffs, a Mexican American couple, purchased a home in defendants' neighborhood); Forkosch, An Analysis of the Prima Facie Tort Cause of Action, 42 Cornell L. Rev. 465 (1957); Comment, Prima Facie Tort, 11 Cumberland L. Rev. 113 (1980).

${ }^{197}$ E.g., Pavesich v. New England Life Ins. Co., 122 Ga. 190, 50 S.E. 68 (1905). See Warren \& Brandeis, The Right to Privacy, 4 Harv. L. Rev. 193 (1890).

${ }^{198}$ E.g., State Rubbish Collectors Ass'n v. Siliznoff, 38 Cal. 2d 330, 240 P.2d 282 (1952)(en banc). See Magruder, supra note 39.

${ }^{199}$ E.g., Woods v. Lancet, 303 N.Y. 349, 102 N.E.2d 691 (1951). See Note, Prenatal Injury, 38 Wash. L. Rev. 390 (1963)(citing cases). See also Bernier, Mothers as Plaintiffs in Prenatal Tort Liability Cases: Recovery for Physical and Emotional Damages, 4 Harv. Women's L.J. 143 (1981).

${ }^{200}$ W. Prosser, supra note 69, $\$ 1$, at 3-4. See Kujok v. Goldman, 150 N.Y. 


\section{The difficulty of measuring damages}

One objection usually raised to torts that protect emotional well-being is that the intangible and highly subjective interests invaded are difficult to measure and prove. ${ }^{201}$ This objection has been rejected as applied to the tort of invasion of privacy, ${ }^{202}$ however, and is rapidly being surmounted in the case of intentional infliction of emotional distress. ${ }^{203}$ Behavior that injures a person's interest in repose and psychological well-being ${ }^{204}$ is now generally actionable despite the difficulties of measuring damages.

Moreover, a tort for racial insults contains an indisputable element of harm, the affront to dignity. ${ }^{205}$ Professor Michelman and others have argued that the intangible quality of novel interests should not, by itself, preclude valuing them for purposes of compensation. ${ }^{206}$ Juries always can assign a value to such interests and their infringement. ${ }^{207}$ Alternatively, legislatures can

$176,178,44$ N.E. 773,775 (1896); C. Fifoot, History and Sources of the Common Law ch. 4 (1949); Albertsworth, Recognition of New Interests in the Law of Torts, 10 Calif. L. Rev. 461 (1922). But see Zepeda v. Zepeda, 41 Ill. App. 2d 240, 190 N.E.2d 849, cert. denied, 379 U.S. 945 (1963)(drastic change should originate with legislature).

${ }^{201}$ E.g., Western Union v. Wood, 57 F. 471 (5th Cir. 1893); Morgan v. Hightower, 291 Ky. 58, 163 S.W.2d 21 (1942). See Kalven, Privacy in Tort LawWere Warren and Brandeis Wrong?, 31 Law \& Contemp. Probs. 326, 334 (1966). ${ }^{202}$ See W. Prosser, supra note $69, \S 117$, at 815 \& nn.44-46 (citing cases).

${ }^{203}$ See generally id. $\$ 12$, at 52-60 (tracing development of law of intentional infliction of emotional distress).

${ }^{204}$ See generally Amdursky, The Interest in Mental Tranquillity, 13 Buffalo L. Rev. 339 (1964).

${ }^{203}$ See supra text accompanying notes 57-63. Cf. W. Prosser, supra note 69, $\S 10$, at 36 ("The element of personal indignity involved [in battery] always has been given considerable weight.").

${ }^{206}$ See Michelman, Property, Utility and Fairness: Comments on the Ethical Foundation of "Just Compensation" Law, 80 Harv. L. Rev. 1165, 1192 (1967); Yudof, Liability for Constitutional Torts and the Risk-Averse Public School Official, 49 S. Cal. L. Rev. 1322, 1380-81 (1976).

${ }^{207}$ See, e.g., Harris v. Harvey, 605 F.2d 330, 336 (7th Cir. 1979)(jury awarded $\$ 60,000$ compensatory damages); Wiggs v. Courshon, 355 F. Supp. 206, 210 (S.D. Fla. 1973)(jury awarded $\$ 6000$ compensatory damages); Agarwal v. Johnson, 25 Cal. 3d 932, 944, 603 P.2d 58, 65, 160 Cal. Rptr. 141, 148 (1978)(jury award- 
set nominal damages to be recovered for the affront to dignity. ${ }^{208}$

Of course, the law does not compensate for every inconvenience, bumped elbow, jostled shoulder, or offended ear; against many of life's minor misfortunes a "toughening of the mental hide" is the best remedy. ${ }^{209}$ Not every reference to a person's race or color is insulting, nor is every insult addressed to a minority person a racial insult. The cause of action suggested here is limited to language intended to demean by reference to race, which is understood as demeaning by reference to race, and which a reasonable person would recognize as a racial insult. ${ }^{210}$ The psychological or emotional harm alleged in such cases can be proved in the same manner as in other torts that protect psychological well-being. ${ }^{211}$ Expert testimony can be presented to substantiate the claim. Although such harms are to the mind and emotions, the harmful effects of racial speech have been amply studied and documented. ${ }^{212}$

\section{The difficulty of apportioning damages}

A second potential objection to a tort for racial insults is the difficulty of apportioning damages. Of course, if proof of directly related emotional or psychological distress is produced, a defendant should be liable for this and any other reasonably foreseeable damages, such as medical expenses or loss of income.

ed \$16,400 general damages); Haddix v. Port of Seattle, No. 840149 , King. Co. (Wash.) Super. Ct. (July 31, 1978)(reported in Seattle Times, Aug. 1, 1978, § A, at 1 , col. 1)(jury awarded $\$ 200,000$ when plaintiff requested $\$ 145,000$ ).

${ }^{208}$ Cf. Browning v. Slenderella Systems, 54 Wash. 2d 440, 451, 341 P.2d 859,866 (1959)(en banc)(awarding nominal damages in race discrimination case because compensatory damages not proven).

${ }^{209}$ Magruder, supra note 39 , at 1035.

${ }^{210}$ See infra text accompanying notes 274-75.

211 See Battalla v. New York, 10 N.Y.2d 237, $242 \&$ n.5, 176 N.E.2d 729, 731-32 \& n.5, 119 N.Y.S.2d 34, 38 \& n.5 (1961)(must look to quality and genuineness of proof, and rely on expert testimony and ability of court and jury to weed out fraudulent claims). See also W. Prosser, supra note 69, § 54, at 328 (very clear tendency of recent cases is to refuse to admit inability to value mental injuries).

${ }^{212}$ See supra Part I. 
Absent these more tangible harms, juries should be free to set damages, within reasonable limits, in order to deter other wrongdoers. And because racial insults are almost always intentional and malicious, punitive damages may often be appropriate..$^{213}$

Even if the victim proves that the defendant's conduct caused the injury, the defendant may be able to show that the wrongful act, if committed in isolation, would have produced no harm. In other words, the defendant may assert that his or her conduct was only harmful because prior acts of racism rendered the plaintiff vulnerable to racial slurs. Such an assertion need not preclude liability, however, because tort law is reluctant to permit defendants to escape liability simply because other factors played a part in producing the plaintiff's injury. ${ }^{214}$

Of the variety of approaches to apportioning damages, two would be relevant to a tort for racial insults. The first approach is to discount the harm to the victim attributable to the earlier actors and to require the present defendant to pay only for any additional harm. ${ }^{215}$ Dean Prosser gives the example of a physician who negligently inflicts further injury on a patient injured by the defendant; although the defendant "may be" liable for the subsequent injury, the physician would never be liable for the acts of the defendant. ${ }^{216}$ In the case of a racial insult, if the plaintiff's

${ }^{213}$ See, e.g., Harris v. Harvey, 605 F.2d 330, 336 (7th Cir. 1979)(jury awarded $\$ 200,000$ punitive damages); Wiggs v. Courshon, 355 F. Supp. 206, 210 (S.D. Fla. 1973)(jury awarded $\$ 19,000$ punitive damages); Agarwal v. Johnson, $25 \mathrm{Cal}$. 3d 932, 944, 603 P.2d 58, 65, 160 Cal. Rptr. 141, 148 (1978)(jury awarded $\$ 46,000$ general damages); Haddix v. Port of Seattle, No. 840149, King. Co. (Wash.) Super. Ct. (July 31, 1978)(reported in Seattle Times, Aug. 1, 1978, § A, at 1, col. 1)(jury awarded $\$ 200,000$ when plaintiff requested $\$ 145,000$ ).

The goal of deterrence plays an important role in tort law. See, e.g., W. Prosser, supra note $69, \S 2$, at 9-11 (punitive damages). Recently commentators have extolled the virtues of deterrence as a means of achieving desirable social results. See, e.g., G. Calabresi, The Cost of Accidents (1970); Coase, The Problem of Social Cost, 3 J.L. \& Econ. 1 (1960); Posner, A Theory of Negligence, 1 J. Leg. Studies 29 (1972); Developments in the Law: Section 1983 and Federalism, 90 Harv. L. Rev. 1133, 1218-19 (1977).

${ }^{214}$ See generally W. Prosser, supra note $69, \S 52$ (methods of apportioning damages between defendant and other causes and among defendants).

${ }^{215}$ See id. § 52, at 320-21.

${ }^{216}$ Id. (citing cases). 
psychological and financial well-being has been damaged by earlier acts of racism, the present defendant would be required to account only for the incremental harm.

The second approach may be applied when the defendant has acted in concert with others to injure the victim. ${ }^{217}$ The theory of this approach is that the actors, "joint tortfeasors" under the common law, are each a part of a single enterprise, and thus the resulting harm is indivisible. This approach is relevant to a tort for racial insults because the maker of a racial slur necessarily calls upon the entire history of slavery and racial discrimination in this country in order to injure the victim. Thus the defendant is, in effect, a joint tortfeasor along with all others, past and present, who have perpetuated racism. Accordingly, the defendant should be liable for the full extent of the injury caused by the racial insult.

The real problem lurking within the issue of apportioning damages is the question of the plaintiff's susceptibility to racial insults. A defendant could argue that his or her own contribution to the injury was small compared to the overall effect of racism on the plaintiff or that the racial insult could have caused no damage because minority group members are or should be inured to such treatment. Further, the defendant could point to the circumstance that the "eggshell skull" rule, 218 which states that a wrongdoer is liable for damages attributable to the plaintiff's peculiar susceptibility even if this susceptibility was not apparent to the wrongdoer, is not followed in intentional infliction of emotional distress cases. ${ }^{219}$

The counterarguments, however, are more persuasive. That a defendant takes advantage of a plaintiff already harmed by

${ }^{217}$ See id. $\$ 52$, at 296, 314-15.

${ }^{218}$ E.g., Vosburg v. Putney, 80 Wis. 523, 50 N.W. 403 (1891).

${ }^{219}$ See Slocum v. Food Fair Stores of Florida, Inc., 100 So. $2 d 396$ (Fla. 1958)(in answer to customer's query, supermarket clerk replied, "[Y]ou stink to me"; customer sued, alleging "ensuing heart attack and aggravation of pre-existing heart disease"; held, complaint does not state cause of action); Restatement (Second) of Torts $\S 46$ comment $j$ (1965)("The law intervenes only where the distress is so severe that no reasonable man could be expected to endure it."); W. Prosser, supra note $69, \S 12$, at 59 \& n.17 ("[T] he distress [in general] must be such as a reasonable man 'of ordinary sensibilities' would undergo under the circumstances."); supra text accompanying notes 129-33. 
earlier victimization makes the act more, not less, reprehensible; a contrary rule would imply that racial minorities are "fair game" for further abuse merely because previously they have been the object of similar abuse. Further, because a person's race is usually obvious, the maker of a racial insult is exploiting an apparent susceptibility rather than causing an unforeseeable injury, as in the eggshell skull cases. Such an exploitation creates liability even under the doctrine of intentional infliction of emotional distress which recognizes that the "extreme and outrageous" character of the defendant's conduct may be supplied by the defendant's knowledge that the plaintiff is peculiarly susceptible to emotional distress. 220

Surprisingly, only two courts have addressed the problem of apportioning damages in racial insult cases. In Alcorn, ${ }^{221}$ the court stated in a footnote, "[W]e cannot accept defendants' contention that plaintiff, as a truck driver must have become accustomed to such abusive language. Plaintiff's own susceptibility to racial slurs and other discriminatory conduct is a question for the trier of fact, and cannot be determined on demurrer."222 In Contreras, ${ }^{223}$ the court quoted this language with approval, adding, "It is for the trier of fact to determine, taking into account changing social conditions and plaintiff's own susceptibility, whether the particular conduct was sufficient to constitute extreme outrage." ${ }^{224}$ That this issue has arisen in so few cases may suggest that once the liability of the defendants in racial insult cases is proved, the courts will not intervene to deny or reduce recovery because of the problem of apportioning damages.

${ }^{220}$ See Note, Torts: An Analysis of Mental Distress as an Element of Damages and as a Basis of an Independent Cause of Action When Intentionally Caused, 20 Washburn L.J. 106, 116-17 \& n.105 (1980)(citing cases involving pregnant women, children, and sick people); Restatement (Second) of Torts $\S 46$, comment $f$ (1965)("The extreme and outrageous character of the conduct may arise from the actor's knowledge that the other is peculiarly susceptible to emotional distress, by reason of some physical or mental condition or peculiarity.").

${ }^{221}$ See supra text accompanying notes 113-13.

2222 Cal. 3d at 498 n.4, 468 P.2d at 219 n.4, 86 Cal. Rptr. at 91 n.4.

${ }^{223}$ See supra text accompanying notes 1-4.

22488 Wash. 2d at 742,565 P.2d at 1177. 


\section{Fraudulent claims and a flood of litigation}

Because a tort for racial insults, like the other torts that protect psychological well-being, would present complex problems of proof of causation and of damages, it will face the objection that it would encourage fraudulent claims and generate a flood of litigation. ${ }^{225}$ In some jurisdictions, the fear of fraudulent claims is reflected in a rule that denies relief to plaintiffs who suffer no physical harm.226 Apparently, these jurisdictions believe that physical injuries are more easily proved and less easily feigned.227 Whatever its value in other contexts, this limitation is unnecessary in actions for racial insults. If racial invective is aimed at a victim, an infringement of the plaintiff's dignity, at the least, has occurred. Moreover, even if occasional plaintiffs win recoveries based on nonexistent damages, there is no reason to assume that these results would be erroneous more often than is the case in other types of civil litigation. At any rate, both correct and erroneous results would deter future offenses and thus protect the rights of others who cannot or will not seek redress. ${ }^{228}$

The specter of a "flood of litigation" was also raised, and ultimately rejected, ${ }^{229}$ in connection with the torts of invasion of privacy and intentional infliction of emotional distress. Empirical studies show that the volume of litigation in response to the judicial recognition of new torts has not been overwhelming. ${ }^{230}$

${ }^{225}$ See Western Union v. Wood, 57 F. 471, 475 (5th Cir. 1893); C. McCormick, Damages $\S 86$ (1935); W. Prosser, supra note 69, $\S 54$, at 328; Kalven, supra note 201 , at 338 .

${ }^{226}$ See W. Prosser, supra note 69, § 12, at 59-60.

${ }^{227}$ See generally id. $\S 12$, at 50-51 (discussing objections to recovery for mental injuries); id. $\$ 54$, at 328 (same).

${ }^{228}$ See Bloustein, Privacy, Tort Law, and the-Constitution: Is Warren and Brandeis' Tort Petty and Unconstitutional as Well?, 46 Tex. L. Rev. 611, 620 (1968).

${ }^{229}$ See, e.g., Chiucholo v. New England Wholesale Tailors, 84 N.H. 329, 334-35, 150 A. 540, 543 (1930); Samms v. Eccles, 11 Utah 2d 289, 293, 358 P.2d 344, 347 (Utah 1961); Prosser, Intentional Infliction of Emotional Distress: $A$ New Tort, 37 Mich. L. Rev. 874, 877 (1939).

${ }^{230}$ See W. Prosser, supra note 69, § 54, at 327-28; McNiece, Psychic Injury and Tort Liability in New York, 24 St. John's L. Rev. 1, 31 (1949); Wade, Tort 
Moreover, the inconvenience and expense of a lawsuit will adequately deter frivolous or fraudulent claims. It is the role of courts to redress wrongs even at the risk of an increase in judicial business. A "flood of litigation," therefore, would suggest that the courts were performing their function of placing the cost of the harm on the perpetrator. In addition, arguments based on a flood of litigation are most persuasive when adequate nonjudicial remedies are available. But because a tort for racial slurs implicates speech, and thus requires interest-balancing under the first amendment, it may not be possible to rely on nonjudicial forums. 231

\section{Objections Based on the First Amendment}

It is surprising, especially after Collin, ${ }^{232}$ that the question whether racial insults are protected by the first amendment has not arisen in any case involving a racial insult. Until it does, the extent to which free speech considerations would shape the cause of action must remain an open question. No reported decision is on point; analysis can proceed only by examination of the nature of racial insults and the policies that underlie the first amendment.

Under first amendment doctrine, regulation of expressive activities is scrutinized more closely when directed at content of the speech rather than merely at the time, place, or manner of the speech in question. ${ }^{233}$ Because racial insults differ from ordinary, non-actionable insults ${ }^{234}$ precisely because they use racial

Liability for Abusive and Insulting Language, 4 Vand. L. Rev. 63, 77 (1950).

${ }^{231}$ See, e.g., Thompson v. City of Minneapolis, 300 N.W.2d 763 (Minn. S. Ct. 1980)(newspaper reporter who accompanied city building inspector for one day published inspector's racist remark; inspector discharged under city civil service commission rule prohibiting language "wantonly offensive" to public; held, rule does not violate first amendment either on face or as applied to inspector).

${ }^{232} 578$ F.2d 1197 (7th Cir.), cert. denied, 439 U.S. 916 (1978). See supra text accompanying notes 5-9.

${ }^{233}$ See L. Tribe, supra note 58, § 12-2; Redish, The Content Distinction in First Amendment Analysis, 34 Stan. L. Rev. 113, 113 \& n.3 (1981)(citing cases). But see Redish, supra (criticizing this distinction).

${ }^{234}$ See W. Prosser, supra note 69, § 12, at 54-55. 
terms for the purpose of demeaning the victim, a tort for racial insults will almost surely be seen as a regulation of content and thus be subject to the more exacting scrutiny afforded in such cases. But regardless of the standard applied, courts ultimately must balance the government's interest against that of the utterer of the infringed speech. ${ }^{235}$

\section{The Government Interests}

The primary government interest served by a tort action for racial insults is the elimination of the harms of racism and racial insults discussed earlier. ${ }^{236}$ Not only the victim of a racial insult but also his or her children, ${ }^{237}$ future generations, ${ }^{238}$ and our entire society ${ }^{239}$ are harmed by racial invective and the tradition of racism which it furthers.

The government also has an interest in regulating the use of words harmful in themselves. In Chaplinsky v. New Hampshire, ${ }^{240}$ the United States Supreme Court stated that words which "by their very utterance inflict injury or tend to incite an immediate breach of the peace" are not protected by the first amendment. ${ }^{241}$ Racial insults, and even some of the words which

${ }^{235}$ See L. Tribe, supra note $58, \S 12-2$, at 583 (impossible to escape task of weighing the competing interests); Shiffrin, Defamatory Non-Media Speech and First Amendment Methodology, 25 U.C.L.A. L. Rev. 915, 962 (1978)(arguing that Supreme Court follows a "general balancing approach" in first amendment cases, in some cases applying general rules while in others engaging in ad hoc decision making).

${ }^{236}$ See supra Part I.

${ }^{237}$ See supra text accompanying note 29.

${ }^{238}$ See supra text accompanying notes 44-53.

${ }^{239}$ See supra text accompanying notes 40-43.

240315 U.S. 568 (1942).

${ }^{241}$ Id. at 572. Although Chaplinsky was a "fighting words" case, and thus its statement about words which inflict injury "by their very utterance" arguably should not be read as a constitutional mandate, this clause has been quoted with approval by the Court as recently as 1974 . See Lewis v. City of New Orleans (Lewis II), 415 U.S. 130, 133 (1974)(quoting Gooding v. Wilson, 405 U.S. 518, 525 (1972)).

Apparently, the Court never has overturned a conviction for "fighting words" except on an overbreadth analysis. For convictions overturned on an overbreadth 
might be used in a racial insult, inflict injury by their very utterance. ${ }^{242}$ Words such as "nigger" and "spick" are badges of degradation even when used between friends; these words have no other connotation.

The Supreme Court also has recognized that in some contexts the government may restrict speech directed at a captive or unwilling audience. These cases have concerned speech both inside $^{243}$ and outside ${ }^{244}$ the home. However, in Cohen v. Califor$n$ nia $^{245}$ the Court overturned a conviction for wearing a jacket with the words "Fuck the Draft" written on it. In meeting the state's argument that the message was thrust upon unwilling listeners, the Court pointed out that viewers could simply avert their eyes. ${ }^{246}$

analysis, see Lewis v. City of New Orleans (Lewis II), 415 U.S. 130 (1974); Plummer v. City of Columbus, 414 U.S. 2 (1973)(per curiam); Rosenfeld v. New Jersey, 408 U.S. 901 (1972); Gooding v. Wilson, 405 U.S. 518 (1972); Terminiello v. Chicago, 337 U.S. 1 (1949). See also Erznoznik v. City of Jacksonville, 422 U.S. 205, 211, 215 n.13 (1975)(striking down, as content-based discrimination, ordinance prohibiting drive-in motion picture theaters from exhibiting films containing nudity where screen visible from street, but implying that a "narrowly drawn nondiscriminatory traffic regulation requiring screening of drive-in theatres from public view" would be constitutional).

${ }^{242}$ See generally L. Tribe, supra note 58, $\S 12-8$, at 606 (what separates utterances which falsely damage reputation or reveal intimate secrets from other speech is that "'more talk' is exceedingly unlikely to cure the injury").

${ }^{243}$ Rowan v. United States Post Office Dep”t, 397 U.S. 728 (1970); Breard v. Alexandria, 341 U.S. 622 (1951); Kovacs v. Cooper, 336 U.S. 77 (1949). But see Martin v. Struthers, 319 U.S. 141, 149 (1943)(striking down ordinance prohibiting summoning resident to door in order to distribute handbills; Breard Court claimed Martin held ordinance invalid "as applied to the free distribution of dodgers 'advertising a religious meeting,'" 341 U.S. at 642).

${ }^{244}$ FCC v. Pacifica Found., 438 U.S. 726 (1978); Young v. American Mini Theatres, Inc., 427 U.S. 50 (1976)(plurality opinion); Lehman v. City of Shaker Heights, 418 U.S. 298 (1974). But see Erznoznik v. City of Jacksonville, 422 U.S. 205, 211, 215 n.13 (1975)(striking down, as content-based discrimination, ordinance prohibiting drive-in motion picture theaters from exhibiting films containing nudity where screen visible from street, but implying that a "narrowly drawn nondiscriminatory traffic regulation requiring screening of drive-in theatres from public view" would be constitutional).

245403 U.S. 15 (1971).

${ }^{246} \mathrm{Id}$. at 20. 
Racial insults are easily distinguishable from the inscription in Cohen. One cannot avert one's ears from an insult. More importantly, a racial insult is directed at a particular victim; it is analogous to the statement "Fuck you," not the statement "Fuck the Draft."247 Finally, a racial insult, unlike the slogan in Cohen, ${ }^{248}$ is not political speech; ${ }^{249}$ its perpetrator intends not to discover truth or advocate social action but to injure the victim. ${ }^{250}$

\section{The Free Speech Interests}

Examination of the free speech values served by a racial insult is best undertaken within the framework of the categories outlined by Professor Emerson in his seminal article, Toward a General Theory of the First Amendment. ${ }^{251}$ Four categories of values are suggested by Professor Emerson: individual selffulfillment; ascertainment of the truth; securing participation by the members of society in social and political decision making; and maintaining of the balance between stability and change.

\section{a. Individual Self-Fulfillment}

The values of individual self-fulfillment to be furthered through free expression are based on the rights of individuals to

${ }^{247}$ Professor Tribe has found in Cohen acknowledgment, at least, of a privacy interest in not being put "on the spot," that is, a right to "resist public scrutiny of [one's] response" to powerful stimuli. See L. Tribe, supra note 58, $\S 12-19$, at 681 .

${ }^{248}$ See 403 U.S. at 18 (recognizing the political content of the slogan in Cohen).

${ }^{249}$ See infra text accompanying notes $258-60$.

${ }^{250}$ In Beauharnais v. Illinois, 343 U.S. 250 (1952), the Supreme Court upheld a criminal statute prohibiting the defamation of racial groups. Although the continuing validity of Beauharnais is in doubt, see Collin, 578 F.2d at 1205; Anti-Defamation League of B'nai B'rith v. FCC, 403 F.2d 169, 174 n.5 (D.C. Cir. 1968), cert. denied, 394 U.S. 930 (1969); Schauer, Categories and the First Amendment: A Play in Three Acts, 34 Vand. L. Rev. 265, 268 n.17 (1981), it has never been overruled. See Schauer, supra, at 268 n.17. See generally Arkes, Civility and the Restriction of Speech: Rediscovering the Defamation of Groups, 1974 Sup. Ct. Rev. 281, 331 (arguing that the "most odious cases" of group defamation should be subject to criminal liability).

25172 Yale L.J. 877, 878-86 (1963). 
develop their full potentials as members of the human community. ${ }^{252}$ But bigotry, and thus the attendant expression of racism, stifles, rather than furthers, the moral and social growth of the individual who harbors it. ${ }^{253}$ In addition, a racial insult is only in small part an expression of self: it is primarily an attempt to injure through the use of words. ${ }^{254}$ No one would argue that the value of self-fulfillment is not limited by consideration of the effects of one's means of expression on other members of society. Although one may dress in Nazi uniforms and demonstrate before the city hall in Skokie, Illinois, one may not paint swastikas on one's neighbors' doors. 255

\section{b. Ascertainment of the Truth}

Professor Emerson argued that "[t]hrough the acquisition of new knowledge, the toleration of new ideas, the testing of opinion in open competition, the discipline of rethinking its assumptions, a society will be better able to reach common decisions that will meet the needs and aspirations of its members."256 This function of free speech, to achieve the best decisions on matters of interest to all, has been extremely influential in first amendment literature. Indeed, one theory of the first amendment is that the amendment's protections extend only to speech that can be characterized as "political."257 In this respect most racial insults are distinguishable from the expressions found protected in Collin. ${ }^{258}$ The plaintiff in Collin, the National Socialist Party of

${ }^{252}$ See id. at 879-80.

${ }^{233}$ See supra text accompanying notes 37-39.

${ }^{254}$ It is in this sense that racial insults are words that inflict injury by their very utterance and thus are not protected speech. In fact, a racial insult might be seen as not "speech" at all. See Ely, Flag Desecration: A Case Study in the Roles of Categorization and Balancing in First Amendment Analysis, 88 Harv. L. Rev. 1482, 1501 (1975)(yelling "boo" at cardiac patient); supra text accompanying notes 16-22.

${ }^{25 s}$ See infra text accompanying note 262.

${ }^{256}$ Emerson, supra note 251, at 882.

${ }^{257}$ See A. Meiklejohn, Free Speech And Its Relation to Self-Government (1948); A. Meiklejohn, Political Freedom (1960).

${ }^{258}$ See supra text accompanying notes 5-9. 
America, was a political party whose race-related beliefs were only a part of a set of ideals. ${ }^{259}$ But the characteristic most significant in determining the value of racial insults is that they are not intended to inform or convince the listener. Racial insults invite no discourse, and no speech in response can cure the inflicted harm. ${ }^{260}$

Racial insults may usefully be analogized to obscenity. Although the government may regulate obscenity, it may not prohibit expression of the view that obscenity should be protected or that, for example, adultery may be proper behavior. ${ }^{261}$ Similarly, protecting members of racial minorities from injury through racial insults, and society itself from the accumulated harms of racism, is very different from prohibiting espousal of the view that race discrimination is proper. ${ }^{262}$

The reasons the Supreme Court articulated in explaining why obscenity may be regulated are also instructive in analyzing

${ }^{259}$ The opinion states, "Among NSPA's more controversial and generally unacceptable beliefs are that black persons are biologically inferior to white persons, and should be expatriated to Africa as soon as possible; that American Jews have "inordinate... political and financial power" in the world and are "in the forefront of the international Communist revolution." 578 F.2d at 1199 (emphasis added).

${ }^{260}$ See F. Haiman, Speech and Law in a Free Society 425 (1981). Cf. Linmark Assoc., Inc. v. Township of Willingboro, 431 U.S. 85, 97 (1977)("If there be time to expose through discourse the falsehood and fallacies, to avert the evil by the process of education, the remedy to be applied is more speech, not enforced silence." ")(quoting Whitney v. California, 274 U.S. 357, 377 (1927)(Brandeis, J., concurring)); L. Tribe, supra note 58, $\S 12-8$, at 606 (what separates utterances which falsely damage reputation or reveal intimate secrets from other speech is that " 'more talk' is exceedingly unlikely to cure the injury").

${ }^{261}$ Kingsley Int'l Pictures Corp. v. Regents of the Univ. of New York, 360 U.S. 684 (1959). See Paris Adult Theatre I v. Slaton, 413 U.S. 49, 67 (1973)(regulation of obscentity is "distinct from a control of reason and the intellect... . The fantasies of a drug addict are his own and beyond the reach of government, but government regulation of drug sales is not prohibited by the Constitution.").

${ }^{262}$ See generally Young v. American Mini Theatres, Inc., 427 U.S. 50, 70 (1976)(plurality opinion)(upholding regulation of location of new adult motion picture theaters in part because such a regulation does not discriminate based upon "message" or "point of view"). But see id. at 87 (Stewart, J., dissenting)(Young an "aberration"). 
racism and racial insults. In Paris Adult Theatre $I \mathcal{V}$. Slaton, ${ }^{263}$ the Court pointed to the "at least . . . arguable correlation between obscene material and crime"264 and the "right of the Nation and of the States to maintain a decent society." "265 Racial insults, through the racism and race discrimination they further, are severely at odds with the goals of antidiscrimination laws and the commands of the thirteenth amendment. A prohibition of such insults would surely further the government's interest in maintaining a "decent society."

\section{c. Participation in Decision Making}

In a democracy, as Professor Emerson argued, all members of society must be permitted to voice their opinions so that the government's authority is derived in fact "from the consent of the governed."266 Racial insults do not further this goal. On the contrary, they constitute "badges and incidents of slavery"267 and contribute to a stratified society ${ }^{268}$ in which political power is possessed by some and denied to others.

\section{d. The Balance between Stability and Change}

Some of the many evils of the suppression of expression also are effects of racism and racial insults. Professor Emerson mentioned the following arguments, among others, under the rubric of maintaining the balance between stability and change: suppression of discussion substitutes force for logic; suppression of speech promotes institutional rigidity and inability to respond to changing circumstances; free expression leads those who lose

${ }^{263} 413$ U.S. 49 (1973).

${ }^{264} I d$. at 58 (footnote omitted).

${ }^{265} \mathrm{Id}$. at 59-60 (quoting Jacobellis v. Ohio, 378 U.S. 184, 199 (1964)(Warren, C.J., dissenting)). Professor Tribe finds three reasons articulated in Paris, although his third reason appears substantially the same as the second reason given in the text. See $\mathcal{L}$. Tribe, supra note $58, \S 12-16$, at 666-67.

${ }^{266}$ Emerson, supra note 251 , at 883 (quoting The Declaration of Independence para. 2 (U.S. 1776)).

${ }^{267}$ The Civil Rights Cases, 109 U.S. 3, 20 (1883).

${ }^{268}$ See supra text accompanying notes 41-43. 
public controversies to accept the result because they have had an opportunity to convert others to their opinion; and freedom of expression prevents violent upheavals by alerting the government to valid grievances. ${ }^{269}$ But racism, in part through racial slurs, furthers all the evils caused by the suppression of speech. Racism dulls the moral and social senses of its perpetrators, ${ }^{270}$ while disabling its victims from fully participating in society 271 and leaving unprejudiced members of society demoralized. ${ }^{272}$ Bigotry and systems of discrimination continue to exist for no reason other than that the prejudiced are in positions of power or authority. Institutions infected by these ills will be peopled by like-minded individuals and thus will be slow to respond to changing circumstances. Furthermore, racism excludes minorities from participating in the contemplation of public issues because their concerns are discounted by the majority and because they have been demoralized by repeated victimization. And it is painfully clear that this exclusion, not only from political discussion but also from the abundance of our country's wealth, is capable of leading to violent outbreaks. ${ }^{273}$

\section{Elements of the Cause of Action}

In order to prevail in an action for a racial insult, the plaintiff should be required to prove that

Language was addressed to him or her by the defendant that was intended to demean through reference to race; that the plaintiff understood as intended to demean through reference to race; and that a reasonable person would recognize as a racial insult.

Thus, it would be expected that an epithet such as "You damn nigger" would almost always be found actionable, as it is highly

${ }^{269}$ Emerson, supra note 251, at 884-85.

${ }^{270}$ See supra text accompanying notes $37 \& 38$.

271 See supra text accompanying notes $42 \& 43$.

${ }^{272}$ See supra text accompanying note 41 .

${ }^{273}$ See, e.g., Report of the National Advisory Commission on Civil Disorders, supra note 11. 
insulting and highly racial. However, an insult such as "You incompetent fool," directed at a black person by a white, even in a context which made it highly insulting, would not be actionable because it lacks a racial component. "Boy," directed at a young black male, might be actionable, depending on the speaker's intent, the hearer's understanding, and whether a reasonable person would consider it a racial insult in the particular context. "Hey, nigger," spoken affectionately between black persons and used as a greeting, would not be actionable. 274 An insult such as "You dumb honkey," directed at a white person, could be actionable under this formulation of the cause of action, but only in the unusual situations where the plaintiff would suffer harm from such an insult. ${ }^{275}$

The plaintiff may be able to show aggravating circumstances, such as abuse of a position of power or authority 276 or knowledge of the victim's susceptibility to racial insults, which may render punitive damages appropriate. ${ }^{277}$ The common law defenses of privilege ${ }^{278}$ and mistake ${ }^{279}$ may be applicable, and

${ }^{274}$ However, if the language was intended and understood as demeaning, minority plaintiffs could sue other members of the same or another minority group. See generally Mebane, In Carolina: Groving Up Black in the '40s, Time, March 2, 1981, at 6, 7 (excerpt from M. Mebane, Mary (1981)) (maltreatment of "black Black" by lighter-skinned blacks).

${ }^{275}$ The cause of action outlined is intended primarily to protect members of racial minority groups traditionally victimized. However, in some situations racial insults may cause harm when directed at members of the majority. The best example of such a situation would be the insult "You dumb honkey" directed at a white child by a black teacher in a predominantely black school. The potential for psychological harm in such a situation is obvious. And although the basis for the tort, the legacy of slavery and race discrimination, might seem to limit the class of those who can bring such actions to members of traditionally victimized minorities, it is the use of race to make invidious distinctions that is the ultimate evil the tort is designed to combat.

${ }^{276}$ See, e.g., supra text accompanying notes 1-4 \& 113-21.

${ }^{277}$ See supra note 214 \& accompanying text.

${ }^{278} C f$. W. Prosser, supra note $69, \S 114$, at 776-85 (absolute privileges to action for defamation, including judicial and legislative immunities).

${ }^{279}$ See W. Prosser, supra note $69, \S 17$ (mistake as defense to intentional tort). The defense of mistake might lie if, for example, a defendant used a racially offensive word or phrase unaware of its harmful connotation; unaware that the individual to whom it was uttered is a member of a minority group who would 
retraction of the insult may mitigate damages. ${ }^{280}$

\section{Conclusion}

This Article began by considering the serious harms inflicted by racism and racial insults. It found that not only those to whom racial insults are addressed but also the perpetrators and society as a whole are victimized. Perhaps most disturbingly, this review of the social science literature revealed that racism and racial insults influence the parenting practices of minority individuals and have a very great effect on children, thus perpetuating the harms of racism.

Next, the Article considered current legal protection from racial insults. It revealed that although plaintiffs have prevailed in actions based substantially on racial insults, the doctrines under which these plaintiffs sued have inherent limitations which ensure that many victims of racial insults will be unable to recover. Finally, objections to an independent tort for racial insults were considered, and it was concluded that these objections would not preclude the tort. The Article noted that the objections have not been squarely addressed in any case, which may indicate that they have not been considered substantial by courts and practicing lawyers.

An independent tort for racial slurs would protect the interests of personality and equal citizenship that are part of our highest political traditions and moral values, thereby affirming the right of all citizens to lead their lives free from attacks on their dignity and psychological integrity. It is an avenue of redress that deserves explicit judicial recognition.

find it painful and insulting; or unaware that the person toward whom the insult was addressed was within earshot. See generally N.Y. Times, May 12, 1974, at 1 , col. 5 (according to sources, then-President Richard Nixon used words "wop" (referring to Judge Sirica), "Jew boys" (officials at SEC), and "thick-necked Mick" (Patrick Gray) in private conversations in White House).

${ }^{280} C f$. W. Prosser, supra note $69, \S 116$, at 799 (in defamation actions, partial defense of retraction is available if made immediately after the utterance and "so clearly connected with it that in effect it negatives the utterance itself")(footnote omitted). 
